\title{
Review
}

\section{Executive Functions in Birds}

\author{
Katarzyna Bobrowicz 1, 2, *, Samuel Greiff ${ }^{1}$
}

1 Department of Behavioural and Cognitive Sciences, University of Luxembourg

2 Department of Philosophy and Cognitive Science, Lund University

* Correspondence: katarzyna.a.bobrowicz@gmail.com

Simple Summary: Everyday functioning requires dealing with a lot of information, usually so smoothly that we barely notice it. The processes that support smooth processing of such information are called executive functions. In recent years, researchers have become interested in these processes in birds, whom, although long considered "bird-brained" and less clever than mammals, actually parallel mammals in tests of intellectual prowess. Interest in birds' brains and performance is increasing, but an overview of relevant previous findings is lacking. Therefore, in this paper, relevant findings are collected and organized to support further investigations of executive functions in birds.

\begin{abstract}
Executive functions comprise top-down cognitive processes that exert control over information processing, from acquiring information to issuing a behavioural response. These cognitive processes of inhibition, working memory and shifting underpin complex cognitive skills, such as episodic memory and planning, which have been repeatedly investigated in several bird species in recent decades. Until recently, avian executive functions were studied in relatively few bird species, but have gained traction in comparative cognitive research following MacLean and colleagues' large-scale study (2014). Therefore, in this review paper, relevant previous findings are collected and organized to facilitate further investigations of these core cognitive processes in birds. This review can assist in integrating findings from avian and mammalian cognitive research and further current understanding of executive functions' significance and evolution.
\end{abstract}

Keywords: executive functions; executive control; birds; inhibition; working memory; shifting; flexibility

\section{Introduction}

Acquiring, selecting, and acting upon incoming information is central to survival in both predictable and unpredictable environments and has been considered the hallmark of human intelligence: the ability to solve problems and survive in new environments. What information should be acquired, selected and subsequently acted upon is influenced by top-down processes falling under the umbrella term of executive control or executive functions [1-2]. Executive functions support flexible adaptation to the environment whenever the current context mismatches familiar ones, prompting the individual to update previously acquired information and adjust their behavior accordingly [3-4]. Such adjustment relies on a host of cognitive processes, frequently classified into (1) inhibition, which facilitates discarding irrelevant information acquired from the environment or retrieved from memory, and suppressing irrelevant actions; (2) working memory, which temporarily holds and operates on relevant information; and (3) shifting, which allows for switching between different rules and strategies as their relevance changes along with corresponding changes in the environment [5]. These processes have been repeatedly investigated both in humans and in non-human animals over the last century. As research into avian executive functions may provide long-sought insight into the evolution of cognition, interest in such research has recently spiked. This increased interest has created a need to gather and organize previous findings to support streamlining future research 
efforts in this field. Therefore, to guide both beginning and advanced researchers in further investigations of these core executive functions, the current paper reviews studies focusing specifically on avian inhibition, working memory and shifting.

Early research, dating back at least to the 1910s, focused on motor inhibition and delayed responding in animals. Whereas motor inhibition requires suppressing irrelevant motor behaviors in favor of relevant ones (or none at all) and moving around obstacles separating the individual from a given goal [6-8], delayed responding requires holding information in working memory and acting upon it after some delay [9-11]. This early research by Thorndike [7], Köhler [6], and Hunter [10] involved fish, bird, and mammal species, whose behavior was tested in purely observational set-ups. The following decades, from the 1930s to 1960s, witnessed a large uptick in both experimental and observational research on executive functions across mammal species (inhibition: [12-15]; working memory: [16-22]), but bird species were somewhat overlooked until the 1960s (but see [23]), when research on avian inhibition and shifting spiked (inhibition: [24-29]). Since then, interest in avian executive functions has grown considerably (e.g., [8, 30-38]).

The interest in avian executive functions has been fueled by at least two sets of scientific findings that emerged between the 1980s and 2000s. First, multiple studies have shown that avian forebrains, despite major differences in organization and structure, share functional similarities with mammalian brains [39-43]. Second, corvids and parrots were found to parallel great apes on tasks that arguably demand complex cognitive capacities, such as episodic memory [44-50] and planning [51-53]. However, research on avian executive functions has exploded only recently. In 2014, performance on a simple motor inhibition task was compared across 36 mammal and bird species, revealing a correlation between absolute brain volume and success levels on the task [30]. In the study, bird species were vastly outnumbered by mammal species (7 vs. 29) and lacked several corvids and any parrot species, two bird groups that have been found to perform on par with great apes on other cognitive tasks [33]. This underrepresentation of corvids and parrots was soon addressed in two other studies, showing that some of the missing corvid species paralleled great apes on the same motor inhibition task [54], while some of the missing parrot species performed poorly on the task [55]. The latter study with parrots, as well as several studies with other species, highlighted methodological issues that undermined the validity of the task [55-57], but despite potential methodological issues, the 2014 study put a spotlight on executive functions in comparative cognitive research. Even today, the body of relevant theoretical and empirical research continues to grow rapidly, expanding the current state of knowledge on the one hand, and on the other hand, contributing to a discussion on whether comparative studies of executive functions are in fact meaningful and productive $[38,58]$.

Given recent developments, research on avian executive functions will likely continue to grow in the upcoming years. To facilitate further investigations of these core cognitive processes in birds, this review paper aims to gather, organize, and integrate relevant previous findings from neurocognitive and behavioral research. Accordingly, this literature review comprises five main sections: (a) an overview of the neural substrates that support executive functions in the avian brain; thereafter, reviews of research on (b) inhibition, (c) working memory, (d) shifting across bird species, and finally, (e) a discussion of recent critiques of comparative research in executive functions, followed by a summary and conclusions.

\subsection{Material and methods}

This literature review was not a systematic review, and the PRISMA guidelines were not closely followed. Two main strategies were used in the literature search underlying this review paper: (1) a keyword-driven database search, and (2) a separate search, driven by sources authored or used in previous research by the authors. 
(1) Keyword-driven database search

The research question was broken down into key areas: conceptualization of executive functions; neurophysiology of the avian brain, with a special focus on the nidopallium caudolaterale; inhibitory control; working memory and shifting. For each key area, several keywords were generated and a guided search in LUBsearch portal at Lund University (https://www.lub.lu.se/en/find/lubsearch), Google Scholar (https://scholar.google.com/) and Researchgate (https://www.researchgate.net/) was performed. The search was performed between the 1st and the 15th of September, 2021. The following keywords were used:

a. Conceptualization of executive functions: "bird executive function*", "avian executive function", "executive functions Miyake", "executive functions Diamond", "executive prefrontal", "prefrontal function".

b. Neurophysiology of the avian brain: "nidopallium caudolaterale", "bird executive", "bird brain executive", "avian pallium", "Herculano-Houzel”, "Güntürkün", "Colombo".

c. Inhibitory control: "bird inhibition", "bird inhibitory control", "motor selfregulation", "detour", "self-control", "MacLean 2014", "Kabadayi", "van Horik".

d. Working memory: "bird working memory", "avian working memory", "bird delayed response", "delayed matching bird", "Dewsbury", "Hunter".

e. Shifting: "bird task switching", "bird shifting", "bird set-shifting”, “bird cognitive flexibility", "Meier pigeon switching shifting", "Colombo pigeon switching shifting".

Only materials in English, including academic journal articles, reports, books, dissertation/theses, conference materials and reviews well allowed in the initial search, leading to 500-600 hits (the exact number was not recorded at this point). The search was directed only at titles and abstracts of materials. The sources were downloaded and thereafter classified into six groups: conceptualization of executive functions, neurophysiology of the avian brain, inhibition, working memory, shifting, critique of executive functions and methodological considerations. In the process of analysing the collected literature, additional relevant sources were found in reference lists and searched for via LUBsearch. Duplicate papers and non-peer-reviewed articles were removed, leaving books, book chapters, theses and peer-reviewed articles.

Thereafter, inclusion/exclusion criteria were set. For the sections regarding the definitions of executive functions and the neurophysiology of executive functions, data from humans, non-human mammals, and birds was included. For the sections regarding inhibition, working memory and shifting, only studies that involved birds were included; studies with humans and non-human mammals were excluded. In the end, a total of 288 references was deemed relevant for this literature review.

(2) Search driven by sources familiar to the authors

Furthermore, the following references, co-authored or previously used by the authors, were set as additional starting points for literature search:

a. Bobrowicz, K. Memory for Problem Solving: Comparative Studies in Attention, Working and Long-term Memory. PhD, Lund University, Lund, Sweden, 2019.

b. Diekamp, B., Kalt, T., Güntürkün, O. Working memory neurons in pigeons. J Neurosci 2002, 22(4), RC210.

c. Güntürkün, O., Bugnyar, T. Cognition without cortex. Trends Cogn Sci 2016, 20(4), 291-303.

d. Güntürkün, O. The convergent evolution of neural substrates for cognition. Psychol Res 2012, 76(2), 212-219. 
e. Herculano-Houzel, S. Numbers of neurons as biological correlates of cognitive capability. Curr Opin Behav Sci 2017, 16, 1-7.

f. Kabadayi, C., Bobrowicz, K., Osvath, M. The detour paradigm in animal cognition. Anim Cogn 2018, 21(1), 21-35.

g. Kabadayi, C., Taylor, L. A., von Bayern, A. M., Osvath, M. Ravens, New Caledonian crows and jackdaws parallel great apes in motor self-regulation despite smaller brains. Royal Soc Open Science 2016, 3(4), 160104.

h. Kabadayi, C., Krasheninnikova, A., O’Neill, L., Weijer, J.V., Osvath, M., Bayern, A.V. Are parrots poor at motor self-regulation or is the cylinder task poor at measuring it? Animal Cogn 2017, 20, 1137 - 1146.

i. Mogensen, J., Divac, I. The prefrontal 'cortex' in the pigeon. Behavioral evidence. Brain Behav Evol 1982, 21(2-3), 60-66.

j. Olkowicz, S., Kocourek, M., Lučan, R. K., Porteš, M., Fitch, W. T., HerculanoHouzel, S., Němec, P. Birds have primate-like numbers of neurons in the forebrain. PNAS 2016, 113(26), 7255-7260. 


\section{Neural correlates of executive functions in the avian brain}

Executive functions support individuals' flexibility in response to the ever-changing environment. Although birds and mammals can solve cognitively demanding problems with similar speed and flexibility [59], their performance is achieved with different-looking brains. In this section, relevant homologies between mammalian and avian brains, as well as the relevance of key brain areas in executive functions research will be discussed. Since birds' and mammals' evolutionary lines separated around 300 million years ago [60], the organization of their pallium differs considerably (3, 40, 61-63). In mammals, the pallium consists mostly of a laminated cortex, but in birds, the pallium does not follow this laminar organization, and is organized in nuclei instead, leading to apparent dissimilarities between the avian and the mammalian "cortex" $(3 ; 5 ; 63-65)$. This apparent dissimilarity led to an assumption of profound differences between the more developed mammalian brain, seen as supporting complex cognition (e.g., flexible memory skills), and the less developed avian brain, with limited access to complex cognition [66]. This assumption has been challenged in the last decades, as numerous anatomical, physiological, and functional homologies between avian and mammalian brains were discovered [67-69]. These homologies were consistent with on-par behavioural performance of, e.g., some corvids and great apes on a simple motor inhibition task [30; 54].

In fact, birds and mammals share a highly comparable network organization of the connectome [3,70], consisting of modular networks with a so-called connective core with an executive hub at the centre [71]. In mammals, the executive hub is embodied by the prefrontal cortex (PFC), an associative forebrain area that integrates multimodal information and matches it with subsequent behavioural responses [72]. Birds do not have a prefrontal cortex, but they do have its functional equivalent, namely, the nidopallium caudolaterale (NCL). Both structures share similar patterns of connections that deliver and send out information [72-73], and both mediate between secondary sensory areas [73-76] and motor and limbic areas of the brain [75-76].

The centres of the avian and the mammalian connectomes, the NCL and PFC, respectively, share not only anatomical and physiological $[39 ; 41 ; 43 ; 61 ; 77-80]$ but, importantly, also functional similarities. Both areas have been repeatedly found to mediate the core executive functions in the healthy brain and to cease doing so upon damage $[3 ; 33 ; 39-42$; 72; 81-84]. Mediation of the core EFs depends on neurochemical connections to structures serving limbic, visceral, and memory functions [85]. Such connections characterize both the NCL and the PFC, both densely innervated by dopaminergic fibers [61; 79; 85-88]. As dopamine is a key neurotransmitter that supports two critical tasks of working memory, namely holding information temporarily and operating on this held information [61, 8990], such dopaminergic innervation is central for the executive tasks carried out by the NCL.

Mapping out the dopaminergic innervation of the NCL was recently used to show that the NCL trajectory differs between two songbirds, the carrion crow (Corvus corone) and zebra finch (Taeniopygia guttata), and two more basal birds, the chicken (Gallus gallus) and pigeon (Columba livia). Some songbirds, but not more basal birds, were found to parallel great apes on cognitive tasks (e.g., [33; 54; 91]), and this finding may be reflected in their respective NCL trajectories. Indeed, these trajectories differed across the tested species, with denser and more diverse dopaminergic innervation in the two songbirds compared to the chicken and pigeon. Furthermore, the NCL was vastly more extensive in the songbird brain than in the pigeon and chicken brain, with at least three separate subareas spanning across the entire caudal nidopallium in the songbirds, but not in the chicken or pigeon [92]. These findings are consistent with other differences in brain structure across bird species. For instance, birds that perform on par with nonhuman primates, e.g., some parrots and songbirds, have higher neuronal densities and disproportionally enlarged nidopallial areas than more basal birds, whose brains have lower neuron numbers and whose nidopallial areas are relatively proportional to other brain structures [92-94]. 
The reorganization of nidopallium may have occurred 56 million years ago with the rise of songbirds, that is, around 250 million years after the last common ancestor of songbirds and non-human primates [92;95-96]. This suggests that the brains of songbirds and non-human primates evolved independently and converged on similar connectivity of neural circuits, function, and generated cognitive performance [61,91]. In fact, some songbirds and parrots have been found to have twice the packing density of pallial neurons as non-human primates [94], which means that their pallium has far more information processing neuronal units than mammalian cortices of equivalent size $[64 ; 94]$. As the packing density of pallial neurons, regardless of pallial, brain or body size, might be the best predictor of cognitive performance [64; 83], these groups of birds cannot be overlooked in research on executive functions, and particularly in large-scale cross-species comparisons (e.g., [30]). Relevant research in the 20th century focused on more basal birds, predominantly pigeons, but more recently, a broader range of bird species, including corvids [97104], have become involved in studies of EFs.

Birds, just like mammals, can flexibly organize their behaviour thanks to an executive centre in their brain, and this is also true when they are confronted with changes in the environment [40]. Although definitions of executive functions typically concur on a topdown, controlling role, definitions vary across subfields of comparative cognitive research. In the neurocognitive studies reviewed in this paper, executive control typically does not comprise concrete, separate core EFs, but takes different forms responsible for the broad tasks of inhibiting, updating, and shifting (e.g., [3; 72]). Most such studies focus on working memory rather than inhibition or shifting. Conversely, in the behavioural studies reviewed in this paper, executive functions are typically defined as the host of core cognitive processes involved in inhibition, (updating) working memory and shifting attention, memory, and behaviour (e.g., [5; 32; 105-106]). All these core processes are investigated. This definition draws on Miyake and colleagues' [2] and Diamond's [1] conceptualizations of EFs, in which executive functions depend on shared but separable mental resources (see also previous research with humans; e.g., [107-112]. Both of these conceptualizations identify inhibition, updating and shifting as the core EFs, but Diamond's definitions of these specific EFs are somewhat broader. According to Diamond, inhibition denotes suppressing currently irrelevant information acquired from the environment (selective attention) and retrieved from memory (cognitive inhibition), as well as refraining from dominant, prepotent, but unproductive behavioural responses in both immediate (motor inhibition, motor self-regulation) and delayed contexts (self-control; [1]). According to Miyake and colleagues, however, inhibition pertains only to prepotent behavioural responses [2]; hence, applying Miyake and colleagues' definition significantly narrows the scope of inhibition research.

With respect to working memory, the definitions are similar in both accounts, as working memory is posited as responsible for holding, updating and monitoring currently used information. Shifting (also set-shifting, task-switching, cognitive flexibility, mental flexibility, mental set shifting; [1]) is in both accounts defined in a way that can be misleading in comparative cognitive research, namely as switching between mental sets or tasks [2] or switching between different perspectives and creative thinking, not switching between two behavioural responses [1]. As such, shifting requires both inhibition and working memory because it demands maintaining at least two different sets of contextresponse contingencies ("In context A, I perform action a; in context B, I perform action $\left.b^{\prime \prime}\right)$ and inhibiting the currently irrelevant response in favour of the relevant one. In nonhuman animals, shifting can be measured in serial reversal tasks, in which the animal learns two responses to two contexts and needs to switch back and forth between these responses over the course of the experiment. However, a reversal task should not by default be considered a shifting task, at least according to the aforementioned definitions, if the rules of the task do not need to be maintained and switched in working memory (see also [113]). Several comparative cognitive studies involve reversal tasks as a measure of cognitive flexibility (another term for task-switching, or shifting in [1]). However, while 
performance on reversal tasks reflects animals' behavioural flexibility, such tasks measure inhibition by default, and shifting only in some cases.

Table 1. Overview of key terms used in this review.

\begin{tabular}{|c|c|}
\hline Term & Definition \\
\hline $\begin{array}{l}\text { Inhibitory control / } \\
\text { Inhibition }\end{array}$ & $\begin{array}{l}\text { Controlled, intentional suppression of currently irrelevant information; supports overriding } \\
\text { dominant or automatic response pulls in favour of more productive responses that eventually } \\
\text { lead to a more rewarding goal }\end{array}$ \\
\hline $\begin{array}{l}\text { Motor self-regulation / } \\
\text { Motor inhibition / } \\
\text { Behavioural inhibition }\end{array}$ & $\begin{array}{l}\text { A basic inhibitory mechanism that allows suppressing a prepotent but counterproductive mo- } \\
\text { tor response in favour of a productive one }\end{array}$ \\
\hline Self-control & $\begin{array}{l}\text { Inhibition of a motor response directed toward a less attractive reward in the present in fa- } \\
\text { vour of a motor response directed toward a more attractive reward in the future }\end{array}$ \\
\hline $\begin{array}{l}\text { Working memory / } \\
\text { Updating }\end{array}$ & $\begin{array}{l}\text { A host of cognitive processes that support holding, updating and monitoring currently used } \\
\text { information }\end{array}$ \\
\hline $\begin{array}{l}\text { hifting / Task-switch- } \\
\text { ing / Cognitive } \\
\text { flexibility }\end{array}$ & $\begin{array}{l}\text { A host of cognitive processes that support switching between mental sets/tasks, or switching } \\
\text { between different perspectives and creative thinking }\end{array}$ \\
\hline
\end{tabular}

Reversal tasks have been repeatedly used to determine which neural substrates support avian executive functions (e.g., [41; 114-116]). As expected, damage to the NCL impairs performance on reversal tasks [114], but damage to at least three other substrates, the Wulst, the medial lobus parolfactorius (LPO) and the hippocampal formation, likewise cause deficits in reversal learning. These deficits have been studied using the repeated acquisition procedure and a card sorting test analogous to the Wisconsin Card Sorting Test for humans, both devised by Watanabe to investigate shifting in pigeons [114]. In contrast to serial reversal tasks, for example, where the animal needs to shift between two context-response contingencies, in the repeated acquisition procedure, the animal needs to learn a new response sequence to the same context each time they master the previously correct response sequence [114; 117]. In the card sorting task, the animal must repeatedly match two stimuli to uncover which match and thus which response, is correct in the current context. The context typically changes after 10 responses, requiring the animal to match the stimuli in other ways to uncover the new correct matching response. It was found that, after damage to the Wulst, pigeons had difficulty uncovering the new correct response, but otherwise this substate's contribution to shifting remains unclear [114]. Damage to the LPO resulted in poorer motor inhibition and an increased number of errors when searching for the correct response and, like damage to the Wulst, impaired finding the correct response [114-115; 118]. Conversely, damage to the hippocampal formation, an avian analogue of the mammalian hippocampus [114; 119-122], resulted in an increased number of trials before finding the correct response, suggesting poorer consolidation of the newly learned contingencies [114]. Damage to the hippocampal formation may, however, result only in spatial working memory but not non-spatial working memory impairments [123-127].

Several brain structures that support avian executive functions have been identified and discussed in this section, with the NCL as the key, supramodal structure that links perception and action in birds. Uncovering parallels between the NCL and its mammalian counterpart, the PFC, played a central role in recent uptick in research on executive functions in birds. Both this recent research and relevant previous findings are classified and discussed under the core executive functions of inhibition, working memory and shifting in the following sections of this review. Each subsection comprises a short introduction and an overview of tasks used to test each executive function. The findings are organized according to the tasks. 


\section{Inhibition}

Inhibition, or inhibitory control, is a suppression of currently irrelevant information, either acquired from the environment (selective attention) or available in memory (intentional forgetting), dominant motivational states, and currently inappropriate responses in favour of information, motivational states and responses that result in optimal, productive behaviours. For instance, an individual may need to suppress a direct reach for a reward that would result in bumping into a barrier in favour of taking a longer, roundabout path around the barrier to retrieve the reward. Definitions of inhibitory control and methods used to investigate this core executive function are provided in this section.

Definitions of inhibition typically highlight that such suppression is controlled and intended by the individual, and serves to override dominant or automatic, internal or external pulls in order to execute a course of action that will ultimately allow the individual to achieve a more rewarding goal $(1 ; 2 ; 56 ; 105 ; 128-129)$. Ease in exercising inhibition differs across individuals within a given species [56; 106]. Therefore, although performance on tasks that demand, e.g., motor inhibition, has been found to differ across bird species [30; 54-55, 130-133], intra-species variation in inhibition needs special attention when interpreting such inter-species differences. The need for well-developed inhibition depends on a range of factors, from position in the group (subordinate vs. dominant; [133]) to selective pressures that regulate survival of a given species, e.g., predictability of the environment [106; 128; 134].

Two components of inhibitory control, motor self-regulation and self-control, have dominated research on avian inhibitory control. Although sometimes confused [30; 130; 135-136), these terms denote two different components of inhibitory control. Motor selfregulation (also: motor inhibition, behavioural inhibition) is a basic inhibitory mechanism that enables suppressing a prepotent but counterproductive motor response to a salient perceptual stimulus in favour of a productive one [54-55; 135]. Motor self-regulation promotes more optimal behavioural responses in both immediate contexts, where receiving a reward requires navigating around a barrier (reviewed in [8]) or changing one's trajectory when the reward location changes [137], and delayed contexts, where receiving a reward requires waiting until a dominant conspecific moves away from the reward [133]. While motor self-regulation promotes choices that secure a reward over a lack thereof, self-control promotes choices that secure a larger or more attractive reward over a smaller or less attractive one. Therefore, self-control involves inhibiting a motor response directed toward a less attractive reward in the present in favour of a motor response toward a more attractive reward in the future (reviewed in [105]). The tension between the immediate, smaller gain and the delayed, larger gain arguably involves not only control over one's behaviour, but also regulation of one's emotions and desires [1].

Another component of inhibitory control, that is, suppressing prepotent mental representations [1; 138], has been investigated to a far lesser extent than motor self-regulation and self-control (e.g., [139]). Such so-called cognitive inhibition supports resisting interference from information acquired before (proactive) or after (retroactive) relevant information (e.g., [139]). This component of inhibition may be more closely related to components of working memory than to other components of inhibition [1; 141-142]. The other components of inhibition, that is, motor self-regulation and self-control, may also be neurologically dissociable from one another, at least in humans [143-145], but whether this dissociation applies to birds needs further examination. 


\subsection{Motor self-regulation tasks}

An array of detour tasks (e.g., [8; 132-133], A-not-B tasks (e.g., [30; 146], and various reversal tasks (e.g.,41; 132; 137; 147]) have been devised to measure avian motor selfregulation. Note that some reversal tasks may be considered measures of shifting, not only motor inhibition, or according to a recent critique, measures of associative learning [148]. This recent critique suggests that performance on discrete stop-signal and stopchange tasks may be sufficiently explained by a model that does not assume involvement of executive control ([148-149]; for a counterargument, see [150]).

\subsubsection{Detour tasks}

In a typical detour task, the animal needs to inhibit moving directly toward a reward and instead go around a barrier to avoid bumping into its surface. Barriers of diverse shapes (e.g., a cylinder, a I-shaped wall, a U-shaped wall), opacity (opaque, semitransparent, transparent) and materials (e.g., mesh, plastic) have been used with different bird species (see Table 2). In detour tasks, it is assumed that the reward, usually visible behind the barrier, induces a strong perceptual pull for an automatic, direct reach, and therefore, acting upon that pull indicates poor motor self-regulation. Touching the barrier, however, may also indicate an animal's need to explore the physical properties of the barrier or, at least in the initial trials, poor visibility of the barrier and/or misunderstanding of the goal of the task [55]. Although testing on non-opaque barriers is usually preceded by training on opaque counterparts, exploiting similarities between the two barriers likely requires other cognitive capacities than only motor self-regulation [8; $30 ; 56]$. These confounding factors must be considered when performance on a given detour task is compared across several species.

Table 2. Overview of EF tasks tested with bird species.

\begin{tabular}{|c|c|c|c|}
\hline Core EF & Task & Species & Source \\
\hline \multirow{23}{*}{ Inhibition } & \multirow{23}{*}{ Detour task } & African grey parrot (Psittacus erithacus) & $55 ; 154$ \\
\hline & & $\begin{array}{l}\text { Australian magpie (Cracticus tibicen dorsalis } \\
\qquad \text { / Gymnorhina tibicen dorsalis) }\end{array}$ & 168 \\
\hline & & Black-billed magpie (Pica hudsonia) & 153 \\
\hline & & Blue-and-gold macaw (Ara ararauna) & 154 \\
\hline & & Blue-headed macaw (Primolius couloni) & $55 ; 154$ \\
\hline & & Blue-throated macaw (Ara glaucogularis) & $55 ; 154$ \\
\hline & & Budgerigar (Melopsittacus undulatus) & 196 \\
\hline & & Clark's nutcracker (Nucifraga columbiana) & 133 \\
\hline & & Common raven (Corvus corax) & $54 ; 152$ \\
\hline & & Domestic chicken (Gallus gallus domesticus) & $6-7 ; 24-25$ \\
\hline & & Domestic pigeon (Columba livia) & $30 ; 151$ \\
\hline & & Eurasian jackdaw (Corvus monedula) & $6 ; 54$ \\
\hline & & Eurasian jay (Garrulus glandarius) & 30 \\
\hline & & Great green macaw (Ara ambiguus) & $55 ; 154$ \\
\hline & & Great tit (Parus major) & $130-131$ \\
\hline & & $\begin{array}{c}\text { New Caledonian crow (Corvus monedu- } \\
\text { loides) }\end{array}$ & 54 \\
\hline & & New Zealand robin (Petroica longpipes) & $147 ; 155$ \\
\hline & & $\begin{array}{c}\text { Orange-winged amazon (Amazona } \\
\text { amazonica) }\end{array}$ & 30 \\
\hline & & Pheasant (Phasianus colchicus) & $38 ; 56 ; 106 ; 128$ \\
\hline & & Song sparrow (Melospiza melodia) & $132 ; 161$ \\
\hline & & Sulphur-crested cockatoo (Cacatua galerita) & 6 \\
\hline & & Swamp sparrow (Melospiza georgiana) & 30 \\
\hline & & Western scrub jay (Aphelocoma californica) & $30 ; 153$ \\
\hline
\end{tabular}




\begin{tabular}{|c|c|c|c|}
\hline & & Zebra finch (Taeniopygia guttata) & 30 \\
\hline \multirow{5}{*}{ Inhibition } & \multirow{5}{*}{ A-not-B task } & Domestic pigeon (Columba livia) & 30 \\
\hline & & Eurasian jackdaw (Corvus monedula) & 146 \\
\hline & & Eurasian jay (Garrulus glandarius) & 30 \\
\hline & & $\begin{array}{c}\text { Orange-winged amazon (Amazona } \\
\text { amazonica) }\end{array}$ & 30 \\
\hline & & Western scrub jay (Aphelocoma californica) & 30 \\
\hline \multirow{40}{*}{ Inhibition } & \multirow{40}{*}{$\begin{array}{l}\text { Reversal learning } \\
\text { task }\end{array}$} & $\begin{array}{l}\text { Australian magpie (Cracticus tibicen dorsalis } \\
\qquad \text { / Gymnorhina tibicen dorsalis) }\end{array}$ & 168 \\
\hline & & Barbados bullfinch (Loxigilla barbadensis) & 159 \\
\hline & & Black-capped chickadee (Parus atricapillus) & 201 \\
\hline & & $\begin{array}{l}\text { Black-headed caique (Pionites melanocepha- } \\
\text { lus) }\end{array}$ & 171 \\
\hline & & Blue jay (Cyanocitta cristata) & 245 \\
\hline & & Bobwhite quail (Colinus virginianus) & $26 ; 158$ \\
\hline & & Budgerigar (Melopsittacus undulatus) & 286 \\
\hline & & Carib grackle (Quiscalus lugubris) & 202 \\
\hline & & Carrion crow (Corvus corone) & $62 ; 287$ \\
\hline & & Clark's nutcracker (Nucifraga columbiana) & $157 ; 165$ \\
\hline & & Common raven (Corvus corax) & $169-170$ \\
\hline & & Dark-eyed junco (Junco hyemalis) & 201 \\
\hline & & Domestic chicken (Gallus gallus domesticus) & $26 ; 158$ \\
\hline & & Domestic pigeon (Columba livia) & $\begin{array}{c}28 ; 41 ; 115 ; 148-149 ; 158 ; 175 ; \\
182\end{array}$ \\
\hline & & Eurasian jay (Corvus monedula) & 146 \\
\hline & & Greater Hill myna (Gracula religiosa) & $27 ; 158$ \\
\hline & & Great-tailed grackle (Quiscalus mexicanus) & 176 \\
\hline & & Great tit (Parus major) & 131 \\
\hline & & Ground finch (Geospiza sp.) & 162 \\
\hline & & Guinea fowl (Numididae) & 158 \\
\hline & & Kea (Nestor notabilis) & 172 \\
\hline & & Indian myna (Acridotheres tristis) & 173 \\
\hline & & Mexican jay (Aphelocoma wollweberi) & 174 \\
\hline & & Mountain chickadee (Poecile gambeli) & $166-167$ \\
\hline & & $\begin{array}{c}\text { New Caledonian crow (Corvus monedu- } \\
\text { loides) }\end{array}$ & 287 \\
\hline & & New Zealand robin (Petroica longpipes) & $147 ; 155$ \\
\hline & & Partridge (Alectoris sp.) & 158 \\
\hline & & Pheasant (Phasianus colchicus) & $37 ; 137$ \\
\hline & & Pinyon jay (Gymnorhinus cyanocephalus) & $157 ; 174$ \\
\hline & & Red-billed blue magpie (Urocissa oecipitalis) & $26 ; 158$ \\
\hline & & Red-shouldered macaw (Diopsittaca nobilis) & 171 \\
\hline & & Ring-necked dove (Streptopelia capicola) & 158 \\
\hline & & Small tree finch (Camarhynchus parvulus) & 204 \\
\hline & & Song sparrow (Melospiza melodia) & $132 ; 161 ; 177$ \\
\hline & & Spotted bowerbird (Chlamydera maculata) & 164 \\
\hline & & Tree finch (Camarhynchus sp.) & 162 \\
\hline & & Trumpeter (Psophia sp.) & 158 \\
\hline & & Western scrub jay (Aphelocoma californica) & $157 ; 174$ \\
\hline & & Woodpecker finch (Cactospiza pallida) & $162-163 ; 203-204$ \\
\hline & & $\begin{array}{l}\text { Yellow-headed parrot (Amazona ochroceph- } \\
\text { ala) }\end{array}$ & $26 ; 158$ \\
\hline
\end{tabular}




\begin{tabular}{|c|c|c|c|}
\hline & & Zenaida dove (Zenaida aurita) & 160 \\
\hline & $\begin{array}{l}\text { Cognitive inhibition } \\
\text { task }\end{array}$ & Goffin's cockatoo (Cacatua goffiniana) & 139 \\
\hline & & African Grey parrot (Psittacus erithacus) & $183 ; 195$ \\
\hline & & Carrion crow (Corvus corone) & $184 ; 192 ; 198$ \\
\hline & Delay maintenance & Common raven (Corvus corax) & $184 ; 192 ; 198$ \\
\hline & task & Domestic pigeon (Columba livia) & $197 ; 289$ \\
\hline & & Goffin's cockatoo (Cacatua goffiniana) & 193 \\
\hline & & Kea (Nestor notabilis) & 194 \\
\hline & Delay choice task & Domestic chicken (Gallus gallus domesticus) & $185 ; 199$ \\
\hline & & Domestic pigeon (Columba livia) & 187 \\
\hline & & Western scrub jay (Aphelocoma californica) & $188-189$ \\
\hline & & Blue jay (Cyanocitta cristata) & 190 \\
\hline & Patch-leaving task & Pinyon jay (Gymnorhinus cyanocephalus) & $191 ; 200$ \\
\hline & & Western scrub jay (Aphelocoma californica) & $188-189$ \\
\hline \multirow{16}{*}{ Working Memory } & \multirow{16}{*}{$\begin{array}{l}\text { Delayed alternation } \\
\text { task }\end{array}$} & Blue tit (Parus caeruleus) & 241 \\
\hline & & Clark's nutcracker (Nucifraga columbiana) & $103 ; 237-239$ \\
\hline & & Coal tit (Parus ater) & 240 \\
\hline & & Common raven (Corvus corax) & $212-213$ \\
\hline & & Domestic chicken (Gallus gallus domesticus) & 98 \\
\hline & & Domestic pigeon (Columba livia) & $\begin{array}{c}42 ; 125 ; 127 ; 230 ; 232-234 ; \\
80 ; 268\end{array}$ \\
\hline & & Eurasian jackdaw (Corvus monedula) & $103 ; 213$ \\
\hline & & Florida scrub jay (Aphelocoma coerulescens) & $103 ; 237-238$ \\
\hline & & Great tit (Parus major) & 240 \\
\hline & & Greenfinch (Carduelis choris) & 240 \\
\hline & & Hooded crow (Corvus cornix) & 98 \\
\hline & & Marsh tit (Parus palustris) & 240 \\
\hline & & Mexican jay (Aphelocoma wollweberi) & 237 \\
\hline & & Noisy miner (Manorina melanocephala) & $241 ; 243$ \\
\hline & & Pinyon jay (Gymnorhinus cyanocephalus) & $103 ; 237-238$ \\
\hline & & Rainbow lorikeet (Trichoglossus haemotodus) & $242-243$ \\
\hline \multirow{4}{*}{ Working memory } & \multirow{4}{*}{ Detour task } & Canary (Serinus canaria) & 246 \\
\hline & & Domestic chicken (Gallus gallus domesticus) & 245 \\
\hline & & Herring gull (Larus cachinnans) & 246 \\
\hline & & Quail (Coturnix sp.) & 246 \\
\hline Working memory & Delayed go no go & Domestic pigeon (Columba livia) & $178 ; 181 ; 247-251$ \\
\hline \multirow{9}{*}{ Working Memory } & \multirow{9}{*}{$\begin{array}{l}\text { Delayed matching- } \\
\text { to-sample }\end{array}$} & Black-capped chickadee (Parus atricapillus) & $124 ; 264$ \\
\hline & & Carrion crow (Corvus corone) & $100-102 ; 208-210 ; 265$ \\
\hline & & Clark's nutcracker (Nucifraga columbiana) & 266 \\
\hline & & Dark-eyed junco (Junco hyemalis) & $124 ; 264$ \\
\hline & & Domestic chicken (Gallus gallus domesticus) & 263 \\
\hline & & Domestic pigeon (Columba livia) & $\begin{array}{c}72 ; 123 ; 225 ; 228-230 ; 252- \\
262 ; 267 ; 269\end{array}$ \\
\hline & & Large-billed crow (Corvus macrorhynchos) & 97 \\
\hline & & Mexican jay (Aphelocoma wollweberi) & 266 \\
\hline & & Pinyon jay (Gymnorhinus cyanocephalus) & 266 \\
\hline
\end{tabular}




\begin{tabular}{|c|c|c|c|}
\hline & & Western scrub jay (Aphelocoma californica) & 266 \\
\hline & \multirow{7}{*}{$\begin{array}{l}\text { Delayed non-match- } \\
\text { ing-to-sample }\end{array}$} & Carrion crow (Corvus corone) & $99 ; 104 ; 208$ \\
\hline & & Clark's nutcracker (Nucifraga columbiana) & $266 ; 270$ \\
\hline & & Domestic pigeon (Columba livia) & $123 ; 217 ; 270$ \\
\hline & & European starling (Sturnus vulgaris) & 271-272 \\
\hline & & Mexican jay (Aphelocoma wollweberi) & 266 \\
\hline & & Pinyon jay (Gymnorhinus cyanocephalus) & 266 \\
\hline & & Western scrub jay (Aphelocoma californica) & $266 ; 270$ \\
\hline & \multirow{4}{*}{ Serial learning task } & Black-capped chickadee (Parus atricapillus) & 223 \\
\hline & & Clark's nutcracker (Nucifraga columbiana) & 165 \\
\hline & & Domestic pigeon (Columba livia) & $140 ; 219-220 ; 222 ; 273$ \\
\hline & & European starling (Sturnus vulgaris) & 224 \\
\hline \multirow{4}{*}{ Shifting } & \multirow{2}{*}{$\begin{array}{l}\text { Dimensional change } \\
\text { task }\end{array}$} & Carrion crow (Corvus corone) & 208 \\
\hline & & Domestic pigeon (Columba livia) & $114 ; 116 ; 118 ; 182 ; 236 ; 276-279$ \\
\hline & \multirow{2}{*}{ Ranking task } & Pinyon jay (Gymnorhinus cyanocephalus) & 284 \\
\hline & & Western scrub jay (Aphelocoma californica) & 284 \\
\hline
\end{tabular}

Before 2014, detour tasks like roundabouts were used to measure motor inhibition in bird species, requiring the individual to move around a flat or irregularly shaped, transparent or semitransparent barrier [6-7; 23; 151]. Although the cylinder task was used already in 2011 to measure motor self-regulation in song sparrows (Melospiza melodia; [132]), it became far more popular in 2014 and afterwards, with the large cross-species study that tested the task with seven bird species [30]. Since then, at least 23 bird species have been tested with the cylinder task, with the results revealing that some corvids, such as ravens (Corvus corax), New Caledonian crows (Corvus moneduloides) and jackdaws (Corvus monedula), outperformed other bird species and performed on par with great apes on this task $[30,54]$. A later developmental study showed that ravens can reach such performance around 10 weeks post hatching [152]. Other corvid species were less successful on the cylinder task $[30 ; 133 ; 153]$, and performed only on par with parrot species tested on the task [30; 154].

As the number of species tested in the cylinder task has increased, its predictive value across bird species has become less and less clear. Initially, performance on the task seemed to correlate with absolute and relative brain size [54], but this was soon challenged by parrots' poor performance [55] and great tits' (Parus major) strong performance on the task [130-131]. In some bird species, such as Clark's nutcrackers, performance on the task correlated positively with dietary breadth [132], but in others, such as pheasants (Phasianus colchicus), this correlation was negative [38]. Furthermore, pheasants were found to perform more poorly on the cylinder and barrier tasks if they had been reared in spatially unpredictable environments [106]. A study with wild North Island robins [155] suggested that poor performance on the cylinder task was predicted by poor individual body condition, pointing toward yet another factor that can potentially blur cross-species comparisons based on the cylinder task.

\subsubsection{Detour tasks}

In the version of the A-not-B task that was described first in the literature, a reward is first hidden in location $A$ in full view of the individual, which is then encouraged to retrieve it [156]. This procedure is usually repeated a couple of times. Thereafter, the reward is hidden in location B, again in full view of the individual, which is supposed to seek out the reward in location B. Searching in the now incorrect location A instead of location B is taken as a sign of poor motor inhibition. A revised version of this task involves an additional, third location that is never used to hide the reward. Furthermore, in the revised version, the reward is moved from location A to location B instead of hidden in location B from the start $[30 ; 32]$. This means that the individual needs to inhibit 
reaching for both location $\mathrm{A}$ and the third, never-baited location. However, the A-not-B task requires not only motor inhibition but also attention to the hands that move the rewards between the two locations [146]. If attending to hand movements is not a part of the cognitive repertoire of a given species, it may perform poorly on the A-not-B task, independently of its inhibitory control predispositions.

At least five species have been tested with the revised version of the A-not-B task [30; 146], and White Carnea pigeons outperformed three corvid and one parrot species on this task. One of the corvid species - New Caledonian crows - was able to outperform White Carnea pigeons only after training on attending to human hands ([146]; $67 \%$ to $54.5 \%$ success).

\subsubsection{Reversal learning tasks}

\subsubsection{Binary choice between colours or locations}

Some reversal tasks require inhibiting a previously rewarded motor response to a certain colour or location. Just as typical detour tasks begin with training on an opaque counterpart of a non-opaque test barrier, reversal tasks in motor inhibition begin with training on a given colour or location [132; 157]. The animal learns that this colour or location is always associated with a reward and passes a trial if, for instance, it flips all lids of the rewarded colour before flipping any of the other-coloured, non-rewarded lids [132]. To test motor inhibition, the colour-reward contingency is reversed; now, the animal needs to inhibit flipping the previously-rewarded lids and go for the other, nowrewarded colour. This procedure is thereafter cyclically repeated over hundreds of trials, demonstrating how fast an individual can learn that the colour-reward contingency has changed.

Among ten bird species tested on a binary choice task in the 1960s, corvids (redbilled blue magpie, Urocissa erythtroryncha), mynas (Sturnidae), parrots (yellow-headed amazons, Amazona oratrix) and pigeons (Columba livia) outperformed doves (Streptopelia capicola), quails (Bobwhite quail, Colinus virginianius), fowls (Guinea fowl, Numididae; White leghorn chicken, Gallus domesticus), partridges (Alectoris sp.) and trumpeters (Psophia sp; [26-27; 158]). This suggested that performance on reversal learning tasks might correlate with the taxonomic position of bird species [position in the tree of life for class Aves; 2627]. In recent years, binary choice tasks have been repeatedly used to measure avian inhibition $[28 ; 38 ; 41 ; 106 ; 132 ; 146-147 ; 155 ; 157 ; 159-177]$, often alongside other tasks that supposedly tap into motor inhibition, such as detour tasks (e.g., [131; 147]). Only a few studies found a correlation between individual performance on a binary choice task and a detour task ([162]; insignificant, [147]), with many showing no such correlation [38; $131-132 ; 147 ; 161]$. Performance on reversal tasks may, however, correlate with predictability of the environment, at least in some bird species. For instance, woodpecker finches from an area with variable food availability outperformed individuals from an area with stable food availability [163]. However, well-developed reversal skills may negatively impact survival rates, at least in pheasants, so perhaps poor inhibition is adaptive in this species [37].

\subsubsection{Discrete stop-signal and stop-change tasks}

In stop-signal tasks, also known as go/no-go tasks, the individual is trained over multiple trials to rapidly respond to a given "Go" stimulus, performing a certain motor response. On some trials, the "Go" stimulus is followed by an additional signal, indicating that the individual should now inhibit the previously trained motor response (e.g., [41; 148-149]). Discrete stop-signal tasks have often been used to test working memory in birds, mostly pigeons (e.g., [41; 178]). This paradigm has a "stop-change" variant, in which instead of just refraining from an irrelevant motor response, the animal needs to employ another, relevant motor response [179-180]. In principle, discrete stop-change tasks may also be considered a measure of shifting, as they involve switching between two context-response contingencies. Discrete stop-signal and stop-change tasks were 
tested with pigeons (Columba livia) to reveal which neural substrates contribute to performance on such tasks (e.g., [41; 178; 181]).

\subsubsection{Continuous stop-change tasks}

Stop-change tasks are continuous versions of stop-signal tasks that do not require training, contrary to detour tasks, A-not-B tasks and stop-change tasks, which makes them an attractive alternative for measuring avian motor inhibition [137]. In stop-change tasks, the individual repeatedly moves toward a certain location to reach a reward. On some trials, however, right before reaching the reward, the location changes, demanding that the individual inhibit movement along the familiar trajectory and begin moving toward the new location instead, before they reach the initial location [137]. In another version of this task, a so-called modified repeated acquisition task, the individual repeatedly acquires and thereafter inhibits a motor response toward one out of three keys [182]. To date, measuring avian motor inhibition in continuous stop-change tasks is not very common, with few species tested on this task (pheasants [137]; pigeons [182]).

\subsection{Self-control tasks}

Avian self-control has been investigated in an array of delay-of-gratification tasks that require refraining from an immediate, smaller gain in favour of a delayed, larger gain (also termed delay discounting; [1]). Delay of gratification across bird species has been tested in delay maintenance tasks (e.g., [183-184], delay choice tasks (e.g., [185-187]) and the patch-leaving task [188-191] (Table 2).

\subsubsection{Delay maintenance tasks}

Two types of delay maintenance tasks have been introduced: exchange and accumulation tasks. At the beginning of an exchange task, an individual receives an immediate but less attractive reward but needs to inhibit consuming the reward in order to receive another, delayed but more attractive one [105]. Throughout the delay, the more attractive reward is usually visible to the individual, and the length of the delay may be signaled to the individual by the experimenter. The trial is terminated when the individual consumes the less attractive reward or waits until the end of the delay and receives the more attractive reward. In an accumulation task, the individual accumulates an increasingly larger reward a few items at a time at a fixed rate. The individual may cash in, that is, acquire the immediately available, but smaller number of items, or wait until later in the procedure for the delayed, larger number of items. The items are assigned to the reward in full view of the individual, either out of reach [183] or within reach of the individual (e.g., [184]).

Several bird species can refrain from consuming an immediate, less attractive reward in favour of receiving a delayed, more attractive one, over delays varying across species, from a few seconds to 15 minutes (common raven, up to $320 \mathrm{~s}$; carrion crow, up to $10 \mathrm{~min}$, [184; 192]; Goffin's cockatoo, up to $80 \mathrm{~s}$, [193]; kea, up to $160 \mathrm{~s}$, [194]; African gray parrot, a few seconds, [105; 183], or up to 15 mins, [195]; White Carneau pigeon, [197]). Interestingly, however, motor inhibition in such tasks seems to depend on the features of the reward; although birds could tolerate long delays when a qualitatively better reward was involved, they had difficulties waiting for larger rewards [184; 193]. Overall, parrots seemed to perform far better on exchange than accumulation tasks [183; 193; 195]. However, birds' performance on exchange tasks may also depend on the familiarity of the human partner [198].

\subsubsection{Delay choice tasks}

In delay choice or intertemporal choice tasks, the individual is required to wait for a more attractive reward or signal opting out, e.g., by pressing a button, to receive an immediate, less attractive reward (e.g., [185-189, 199]). 


\subsubsection{The patch-leaving task}

The patch-leaving task, contrary to delay maintenance tasks and delay choice tasks, begins with a small reward that can be claimed and consumed by an individual without losing a chance to obtain further rewards. After the initial reward, the individual can stay in a given patch, e.g., a specific location, and wait for a further, larger reward, or leave the patch and immediately start another trial, with a guaranteed small reward at the beginning [200]. Arguably, this task may emulate birds' natural environment better than typical delay-of-gratification tasks. So far, this task has been tested in three corvid species, the California scrub jay (Aphelocoma californica, [188-189]), blue jay (Cyanocitta cristata; [190-200]) and pinyon jay (Gymnorhinus cyanocephalus; [191; 200]). These species typically performed better in the patch-leaving task than in other tests of self-control [190].

\subsection{Future directions in inhibition research}

Inhibitory control is central to survival, as it enables refraining from behaviours that are unproductive in the current context. However, the behavioural measures of inhibitory control discussed in this section have been subject to repeated critique in recent years [38; 55; 106, 131; 146]. Several factors may confound individual performance on these tasks and hinder within-species and between-species comparisons, from species-specific sensorimotor capacities to task-specific demands, e.g., attention to human hands and early predictability of the environment. Some of these confounders may be eliminated by using test batteries instead of single tasks (spotted bowerbirds [164]; North Island robins [147; 155]; great tits [131]). To date, only a few bird species have been involved in such test batteries, typically consisting of detour tasks and color reversal tasks alongside other motor and learning tasks [38; 147]. The few conducted studies revealed that some of the measures loaded onto a single factor, showing, according to some researchers, that a general cognitive factor, similar to human " $\mathrm{g}$ ", may underpin avian cognitive performance ([147]; but see [38]). Further studies with test batteries should, however, be treated with caution, as, even if several measures of performance load onto a single factor, this factor may reflect a capacity other than general-domain intelligence ([38]).

Species-specific performance on inhibition tasks may also reflect an adaptive tradeoff in cognition. For instance, research on food-caching species has shown that species with poorer cognitive inhibition may have better memory skills [4]. Species with better spatial memory skills, such as black-capped chickadees (Poecile atricapillus), may have had more difficulty learning a new contingency in reversal tasks than non-caching darkeyed juncos (Junco hyemalis, [201]). Reversals were also relatively difficult for Clark's nutcrackers (Nucifraga columbiana), and it seems that the inhibition-memory trade-off may result in within-species differences, at least in mountain chickadees (Poecile gambeli, $[4 ; 166])$. Among this species of chickadee, high-elevation individuals performed better on memory tasks but worse on reversal tasks than low-elevation individuals. A somewhat similar trade-off between innovativeness and flexibility of learning was found in Indian mynas on problem-solving tasks that demanded innovation [167]. This suggests that within a single species, some individuals may be innovators, and others flexible learners [166]. In general, however, reversal learning tasks may tap into different cognitive capacities than problem-solving tasks. Persistence, which supports success on problem-solving tasks, will likely result in poor performance on reversals ([136; 202]; for no correlation whatsoever, see [162-164; 176; 203-204]).

Inhibition is a critical part of everyday survival, and is relatively easy to test in behavioural set-ups across species with varying sensorimotor skills and ecology.To date, at least 53 bird species have been tested in motor inhibition tasks and at least 11 in selfcontrol tasks (Table 2), making inhibition perhaps the best-researched cognitive capacity in birds. Working memory and shifting, covered in the next sections, build on inhibition in general, and inhibition of attention and memory inhibition in particular. Therefore, 
tasks measuring working memory and shifting will necessarily tap into inhibitory control as well.

\section{Working memory}

Working memory is a core executive function responsible for maintaining information that is no longer available in the environment and actively manipulating it as needed in the current context $[1 ; 81 ; 205-207])$. To date, avian working memory has been repeatedly investigated on a physiological and behavioral level $[99 ; 101 ; 208-211]$ in various set-ups, which are reviewed in this section. The term working memory was first used, alongside the term short-term memory, in the 1950s. These two terms, although sometimes used interchangeably in bird memory research, are not identical [212-213]. Short-term memory supports holding information in the mind; working memory supports holding, updating, and operating on this information. Short-term memory is not considered an executive function, whereas working memory is.

The concept of working memory was defined in parallel and somewhat independently in pigeon and human research. According to Honig [207], coming from pigeon research, working memory comprises information that the animal had to retain and use on a single occasion, and which needs to be actively suppressed or forgotten to avoid interference with previously or subsequently needed information [214]. Therefore, working memory is linked to inhibition in several ways. First, inhibition is responsible for suppressing previously relevant information (interference control/cognitive inhibition; [1]); second, inhibition supports disregarding internal and external distractors (selective attention; [1]). Third, inhibition draws on working memory, using the currently maintained goal to determine what should be suppressed or deleted. Although in avian research, working memory is conceptualized as a cognitive module that is separate from inhibitory control (e.g., [81]), other conceptualizations that emerged in human research assume that working memory is a broader cluster of processes that involves both maintaining selected information in an active, available state and inhibiting irrelevant information at both the attentional and cognitive levels [208-209]. Although this conceptualization may draw more attention in future research with nonhuman species, most observational studies collected for this review build on the first conceptualization, in which inhibition, working memory, and shifting are considered separable constructs (but see [72; 104; 211]).

Working memory has a limited capacity and is governed by chunking strategies. Recently, carrion crows were found to parallel rhesus macaques in working memory capacity for 4 items (colourful squares; [104]) and, in another setup, pigeons were found to share a one-item working memory memory with rhesus macaques [217-218]. Pigeons were also found to chunk sequences of items into smaller portions [219-220], implementing a strategy that increases working memory efficiency. Since working memory capacity determines how much information can be simultaneously manipulated, it may correlate with better performance on cognitive tasks in humans and mammals (e.g., [215; 221]). Although this association has not yet been studied in a bird species, working memory capacity may correlate with better cognitive performance in birds as well [211], as several parallels between avian and mammalian working memory have been drawn. For instance, it was recently shown that carrion crows control their working memory capacity in a top-down manner, utilizing cues that instruct them whether a given stimulus should be retained, regardless of the timing of the instructions - before encoding a stimulus or while maintaining that stimulus in working memory [99]. In other words, crows used attention to maximize working memory capacity, just like humans do [99].

Furthermore, several bird species (pigeons: [141; 222], black-capped chickadees [223]; European starlings [224]; Clark's nutcrackers [165]; ravens [212]; Table 2) are susceptible to serial-position effects, which are likewise found across mammal species, including humans. Whenever a given memory task involves encoding a list of samples, 
some of these samples are remembered better than others. This effect, termed the serialposition effect, usually pertains to samples at the beginning (primacy effect) or at the end of the list (recency effect). These effects seem to be a ubiquitous aspect of working memory in birds and mammals and may be driven by similar underlying mechanisms. A study with pigeons, rhesus macaques, and humans showed that across the three species, the recency effect was stronger than the primacy effect soon after encoding, but over time, the relationship was reversed, with the primacy effect gaining and the recency effect losing strength [140]. Some birds, such as pigeons, share the human susceptibility to procedures that enhance or hinder working memory. On the one hand, pigeons, like humans, exhibit better memory for surprising or novel stimuli than for expected ones, and this effect is more pronounced after a delay than immediately after the stimulus (delayed matching-to-sample; [225-227]; Table 2). On the other hand, pigeons, like humans, can suffer from interference and forgetting when, e.g., a light is turned on in a dim experimental space at the end of the retention interval, in which the individual is supposed to hold certain information [228-230]. Although avian working memory may rely on similar mechanisms as human (and mammalian) working memory, intra- and inter-species variation in working memory has been repeatedly found and typically related to, e.g., food-caching and sociality levels [97].

Avian working memory has been measured with a range of delay tasks, some of which involved reversal learning [39; 41;231]. Delay tasks typically involve a retention interval that is administered between exposure to certain stimuli and the opportunity to issue a behavioural response. These tasks require three general steps: encoding, "online" maintenance, and issuing a behavioral response.

\subsection{Delayed alternation tasks}

In a typical spatial delayed alternation task, an individual needs to navigate a maze consisting at least of three arms; T-shaped, Y-shaped or radial [5]. The individual either starts the task from the longest arm and proceeds to the shorter ones (T-shaped and $\mathrm{Y}$ shaped mazes), or starts from the central hub and proceeds to several arms that radiate outward (radial maze). The individual should usually explore each arm of the maze once, without going back to an already-explored one [232]. Several studies with pigeons showed that they performed well on radial mazes as long as they had sufficient training and the experimenter's presence was limited ([233] but [234]), and interestingly, if the radial maze required walking/running rather than flying [235].

Another version of an eight-compartment maze was used in a dual task, measuring spatial working memory and memory for color cues in pigeons [236]. This task revealed that the dual load on working memory impaired pigeons' performance only a little compared to the single load. To compare spatial working memory across food-caching and non-food-caching species, several corvids were tested in open-space analogs of the radial maze, both two- and three-dimensional. The results revealed, for instance, that Clark's nutcracker, the species that most relied on food-caching, outperformed Mexican jays and scrub jays (two-dimensional [98; 103; 237]; three-dimensional: [238-239]; four tit species, 240). A field version of the delayed alternation task was used to test win-stay and win-shift strategies during foraging in honeyeaters (noisy miners, Manorina melanocephala), parrots (rainbow lorikeets, Trichoglossus haematodus [241-243]) and blue jays [244]. Furthermore, an updated version of the delayed alternation task, utilizing nine-cache matrices instead of mazes, was recently tested in ravens [212]. Each of the nine locations contained a reward, so the individual was supposed to visit each location once, without coming back to an already-explored one. This task has not been tested with other bird species, but may be a good alternative to radial maze tasks, especially in food-caching species.

Finally, in another version of the delayed alternation task, often combined with neurophysiological measurement, the individual is confronted with two response keys, each of which can provide a reward. To keep obtaining rewards, the individual needs to 
continuously alter between the two response keys, with a forced delay between responses that requires remembering which response key should be pressed after the delay $[40 ; 80 ; 231]$.

\subsection{Detour tasks}

Although detour tasks have primarily been used to study motor inhibition, some such tasks that require maintaining a representation of the goal while it was out of sight also allow for measuring working memory in birds. In these tasks, the individual would see the goal at the beginning of the trial, and then would lose sight of the goal while navigating a four-compartment box [245-246]. After seeing the goal behind a transparent or a semitransparent barrier, the individual needs to turn away and head toward one of the opaque compartments, only two of which lead to the goal. Quails and young herring gulls outperformed canaries on this task, perhaps due to diverse species-specific adaptations to navigating the environment [246]. Quails and young herring gulls would typically walk around obstacles, while canaries would fly over them, so they may have been less prepared than the other two species for the four-compartment box in which flying was not possible.

\subsection{Delayed go/no-go}

Delayed Go/No-Go tasks have been repeatedly used to measure working memory in pigeons ([178; 181]; see also 3.1.3.2 and 3.1.3.3). In a typical delayed go/no-go task, a go or no-go sample stimulus is followed by a delay that ends with a signal, after which the response should be either executed (go) or withheld (no-go; [247]). The individual needs to retain the information on the relevant action throughout the delay but may act upon it only once the delay is over (e.g., pigeon [248-250]). A recent study using this paradigm showed sustained neural activation in the pigeon nidopallium caudolaterale on the "go" trials, suggesting that the birds retain only the "go" sample stimulus that requires action by them $[172 ; 247 ; 251]$. This is adaptive: omitting working memory involvement by not retaining the "no-go" stimulus is arguably more efficient than suppressing a motor action at the end of the delay.

\subsection{Delayed matching-to-sample tasks}

In a typical delayed matching-to-sample task, introduced in the 1950s [252], the individual is first presented with sample items and, after a delay, with the same items among other, distracting items. The individual is supposed to retain the sample items over the delay (retention interval) and choose these familiar items from among the other, unfamiliar ones. For instance, at the beginning of a trial, the individual may see one of two colors, both of which were previously associated with rewards. Once the color disappears, the individual needs to maintain the target in working memory and, after the delay, choose a bowl of this color in order to receive the reward (e.g., [211]). This task has been repeatedly tested with several bird species, such as the pigeon $[72 ; 228-230$; 253 262], domestic chicken [263], black-capped chickadee [125; 264], dark-eyed junco [125; 264], large-billed crow [97], carrion crow [202; 265], Mexican jay, pinyon jay, Clark's nutcracker and scrub jay ([270]; Table 2).

During the delay in a matching-to-sample task, pigeons and carrion crows showed sustained activation in NCL neurons, suggesting that this activity may be a neural correlate of working memory for both spatial and non-spatial stimuli, reflecting all of its components, from sensory coding to mnemonic processes and motor preparation [39; 42; $100-101 ; 178 ; 208 ; 231 ; 251 ; 267-268]$. In some studies, this activity would wane as the delay progressed [262], but in others, it would remain constant, even despite varying delays [102; 270]. This suggests that delay-related neural activity in the NCL may in fact represent not "what" should be maintained but the fact "that" something coded elsewhere, e.g., in the primary visual region, should be maintained [269]. On the other hand, the presence of sustained neural activity during the delay in some species and lack thereof in others may reflect different types of working memory strategies used by these species. The pigeon, a non-caching bird, may be less predisposed to attend to the length 
of the delay than the carrion crow, which relies on food-caching and needs to keep track of time in order to retrieve cached food items before they spoil.

Recently, a directed forgetting version of the delayed matching-to-sample task was used to show that a considerable portion of nidopallium caudolaterale neurons support working memory in pigeons [72]. In the directed forgetting version, the individual is instructed by relevant cues to remember or to forget the displayed stimuli. The pigeons were significantly better at choosing the sample after the "remember" cue (highfrequency tone) than after the "forget" cue (low-frequency tone), and this difference was mirrored by neural activation, as only the "remember" cue resulted in sustained neural activation in the retention interval [72]. Auditory cues were also used in another version of the delayed matching-to-sample task, a bimodal delayed paired associate task, tested in carrion crows [102]. Neural activation detected during the delay was interpreted as a sign of reactivated representations of associations between auditory and visual stimuli retrieved from long-term memory.

\subsection{Delayed non-matching-to-sample tasks}

The delayed non-matching-to-sample task follows the same procedure as the delayed matching-to-sample-task, but the individual is supposed to choose the unfamiliar item(s) instead of familiar ones after the delay. Several decades ago, this task was used to compare working memory performance across bird species (Clark's nutcrackers, scrub jays and pigeons [270]; nutcrackers, pinyon jays, Mexican jays, and scrub jays [266]). The food-caching species performed better on spatial working memory tasks than those that do not rely on cached food, but there was no such difference for non-spatial working memory tasks. Recently, another version of this task, a so-called change localization task, was used to study working memory capacity in carrion crows [104], and another, auditory version of the delayed non-matching-to-sample task was tested in European starlings [271-272].

\subsection{Serial learning tasks}

In serial probe recognition tasks, the individual is presented with a series of to-beremembered stimuli, and, after a delay, should choose the stimuli that occurred in this series (e.g., [140; 219; 273]). Pigeons tested on this task showed the same pattern of primacy and recency effects as rhesus macaques and humans [140], with the recency effect strongest at short delays and the primacy effect gaining strength over time. This pattern holds for visual stimuli, but interestingly, an opposite pattern of serial position effects was observed for auditory stimuli, at least in European starlings [224]. Here, the primacy effect was strongest at short delays, and the recency effect gained strength over time. This was attributed to strong initial proactive interference of the first stimuli that waned over time and was replaced with retroactive interference of the most recent stimuli. Proactive interference was found also in another bird, Clark's nutcracker. This food-caching corvid species was tested in serial tasks, with either a single string of rewarded locations or two strings of such locations [165]. The birds displayed a proactive interference effect in the two-string task, with impaired acquisition of the second string of locations after learning the first one.

\subsection{Future directions in working memory research}

For several decades, working memory was predominantly investigated in pigeons tested in various neurocognitive setups. Updated versions of these setups, which allow for measuring sustained neural activation during the delay between the initial presentation of the stimulus and the test, have become increasingly popular in pigeon and crow research $[72 ; 178 ; 247 ; 251 ; 269]$. As these setups may be adapted to virtually all bird species, they may support cross-species comparisons of working memory in the future. However, cross-species comparisons are certainly possible with purely behavioural, non-invasive setups, as long as relevant sensorimotor differences are accounted for. Combined with flourishing knowledge on bird brains, such setups could 
prospectively provide insights into inter- and intra-individual differences in working memory, and the role of working memory in the evolution of cognition.

To date, a vast majority of working memory studies have focused on vision. This is understandable, as this modality is perhaps the most relevant for many bird species, but how birds maintain and operate on information acquired through other modalities needs further research. After all, the NCL, highly involved in working memory operations, is a supramodal processing area, relying on information from multiple modalities. Furthermore, little is known about factors embedded in the physical and social environment that affect working memory processes in birds. For instance, a recent setup tested in ravens, in which an individual needed to keep track of another individual's actions, could potentially reveal different levels of working memory performance within a given species, e.g., according to individual status in the social group, or across species, e.g., according to the typical level of the fission-fusion dynamic in the social group [212].

Overall, working memory has been investigated in at least 24 bird species. Although various set-ups were involved in this research, delayed (non-)matching-to sample paired with neurophysiological measurements in pigeons and carrion crows, and spatial memory studies with food-caching species, were the most popular methods of investigating avian working memory. Along with inhibition, working memory has been investigated far more extensively than shifting (set-shifting, task-switching), reviewed in the next section.

\section{Shifting}

Shifting builds on inhibition and working memory [1] and involves switching between at least two rules, strategies or attentional sets that need to be held in working memory and that require inhibiting currently irrelevant actions [274]. Shifting, also referred to as "task-switching", "set-shifting" or "attention switching", is not engaged when the individual shifts visual attention between items that are currently available in the environment; conversely, shifting is engaged when rules (or strategies, or attentional sets) that guide the choice of these items are held in the individual's working memory [2]. Dimensional change (or shift) tasks are the most popular measures of shifting in birds. So far, however, they have been tested predominantly in the domestic pigeon (Columba livia).

\subsection{Dimensional change tasks}

In some shifting tasks, modelled after the Wisconsin Card Sorting Test for humans [276], the individual is first trained to attend to one dimension of stimuli (e.g., colour or numerosity), and thereafter must switch attention to another dimension of the same stimuli (e.g., shape, location, or variability; [231; 276-278]). This requires inhibition of attention to the previously relevant dimension and maintaining the now-relevant rule in working memory [136]. Although this task is related to reversal learning, it requires the individual to form and shift between multi-dimensional attentional sets in order to succeed.

Pigeons are perhaps the most intensively tested bird species on dimensional shift tasks and have shown impressive performance levels on such tasks (e.g., [277-278]). For instance, they were able to keep switching between two abstract categorization rules (numerosity and variability), with only the colour of the background indicating which rule should be followed on a given trial. For instance, one colour indicated that the pigeons should attend to numerosity (6 vs. 16 items), while another colour indicated that the pigeons should attend to variability of the sets (identical items vs. non-identical items). Pigeons were able to switch fast between these two dimensions, and even transferred the discrimination behaviour to sets of novel items [277]. In another study, pigeons would shift between rules, such as matching to sample vs. non-matching to sample, halfway through a series of trials without any external visual cues, seemingly timing the midpoint on their own [279]. Switching between matching to sample and 
non-matching to sample was also tested in carrion crows [208]. The study followed a classic delayed (non)matching-to-sample procedure, as the crows were informed of the currently relevant rule (match or non-match) by an auditory or visual cue in the delay between the initial stimulus and two test stimuli, one of which was identical to the initial stimulus. The response pattern in the crow NCL indicated that this brain area was critical to performance on this task [208].

It was recently highlighted that several dimensional change studies showing high shifting performance in pigeons involved extensive training and may have relied on pigeons' associative learning rather than on the core executive function of shifting [280]. For instance, despite high performance on tests that involved extensive training, pigeons were not able to exhibit swift shifting between rules in tasks that did not involve such training [276]. In humans, shifting incurs so-called task-switching costs, that is, slower and more erratic performance on switch trials compared to repeat trials [281]. This cost is not detected in pigeons [277] or in monkeys [282-283], leading to the conlusion that pigeon performance may be mediated by associative learning rather than executive functions [280]. However, a recent critique of this conclusion highlighted that pigeons may be able to use the core executive function of shifting without task-switching costs, and these costs in humans may be caused by processes other than executive functions (or factors related exclusively to human executive functions, e.g., language-related; [150]).

\subsection{Ranking tasks}

Not all shifting tasks involve reversal learning. One such task was tested with two corvid species (scrub jays, pinyon jays [284]). In the task, birds ultimately needed to learn a "hierarchy" of six colours ( $\mathrm{A}>\mathrm{B}>\mathrm{C}>\mathrm{D}>\mathrm{E}>\mathrm{F}>\mathrm{G}$ ), e.g., to choose B when paired with $C$ but not when paired with $A$; to choose $D$ when paired with $E, F$ or $G$, but not when paired with $\mathrm{A}, \mathrm{B}$ or $\mathrm{C}$, and so on. This required that the birds maintain a complex set of rules and switch between them depending on the current colour pairing. Interestingly, pinyon jays, which live in large and stable social groups, learned faster and seemed to use a memory strategy that was less prone to error than less social scrub jays [284].

\subsection{Detour tasks}

A detour task may also measure shifting if, for instance, the individual has the option to switch between a repeatedly reinforced but longer route and a shortcut that becomes available later in testing. Chickens tested in this setup seemed to ignore such a shortcut after 75-80 trials of reinforcement on the longer route [7-8].

\subsection{Future directions in shifting research}

Although several bird species have been tested in reversal learning tasks, most of these tasks measured inhibitory control, at least according to the classifications of core executive functions followed in this review [1,2]. Shifting tasks have not been used in cross-species comparisons. This is a pity, given that shifting builds on inhibition and working memory and is most likely a hallmark of well-developed cognition. Differences in shifting capacities may be a much better indicator of cognitive differences across species than differences in inhibition, which might to a larger extent depend on shortterm predictability of the environment. This is an uncharted field of comparative research that needs increased attention in the future.

Furthermore, to date, dimensional change tasks seem to have dominated avian shifting research, but other behavioural methods of measuring shifting are needed in order to, for instance, devise batteries of shifting tasks appropriate for bird species. Other tasks that should, in principle, tap into shifting, such as the ranking task, could gain more traction and inspire further shifting tasks that do not mimic tests initially designed for humans (like the Wisconsin Card Sorting Task or the Dimensional Change Card Sort Task). 


\section{Discussion}

\subsection{Limitations of this literature review}

Findings of this literature review need to be taken with caution. Materials in English dominated the reference list, leading to a potential language bias. As the reviewed field is dynamically developing, the latest findings published after the time of literature search may not have been included here. Furthermore, what may be relevant for a beginning or an advanced researcher, was determined based on previous work of the authors, influencing the shape of this review and contributing to potential authors' bias. The review was not systematic and, although the PRISMA guidelines were consulted, they were not closely followed (see section 1.1).

\subsection{General methodological considerations and conclusions}

Comparative cognitive research on avian executive functions involves a variety of set-ups tested with several bird species (Table 3) and has received increased attention, and critique, in recent years. The large-scale cross-species comparison of performance on two inhibitory control tasks, the cylinder task and the revised A-not-B task, sparked a discussion on the validity of such comparisons and challenges of comparative research [30]. Despite correlations between scores on the inhibitory control tasks and absolute brain size across species, there was no correlation between performance on the inhibitory control tasks at the individual level $[58 ; 285]$. In other words, the fact that correlations across species were found did not imply that any correlations held within species. Furthermore, there was no evidence whatsoever that the two tasks, which were assumed to tap into the same cognitive capacity, did indeed capture it [58]. This is not only the case for the cylinder task and the revised A-not-B task [30; 285], but also for the cylinder task and the binary choice reversal task in several species $[38 ; 131-132 ; 147 ; 161$ 165].

Table 3. Overview of bird species involved in EF research.

\begin{tabular}{|c|c|c|c|}
\hline Group & Species & Core EF & Source \\
\hline $\begin{array}{l}\text { Australasian rob- } \\
\text { ins (Eopsaltridae) }\end{array}$ & New Zealand robin (Petroica longpipes) & Inhibition & $147 ; 155$ \\
\hline \multirow[t]{8}{*}{$\begin{array}{c}\text { Bowerbirds (Pti- } \\
\text { lonorhynicdae) }\end{array}$} & Spotted bowerbird (Chlamydera maculata) & Inhibition & 164 \\
\hline & Black-billed magpie (Pica hudsonia) & Inhibition & 153 \\
\hline & Blue jay (Cyanocitta cristata) & Inhibition & $190 ; 245$ \\
\hline & & Inhibition & $62 ; 184 ; 192 ; 198 ; 287$ \\
\hline & Carrion crow (Corvus corone) & Working memory & $\begin{array}{c}99 ; 100-102 ; 104 ; 208-210 ; \\
265\end{array}$ \\
\hline & & Shifting & 208 \\
\hline & Clark's nutcrackor (Nucifracg columbiana) & Inhibition & $133 ; 157 ; 165$ \\
\hline & Clark's nutcracker (Nucifraga columbiana) & Working memory & $103 ; 165 ; 237-239 ; 266 ; 270$ \\
\hline \multirow{10}{*}{$\begin{array}{l}\text { Corvids (Corvi- } \\
\text { dae) }\end{array}$} & Common raven (Corvus corax) & Inhibition & $\begin{array}{c}54 ; 152 ; 169-170 ; 184 ; 192 ; \\
198\end{array}$ \\
\hline & & Working memory & $212-213$ \\
\hline & & Inhibition & $6 ; 54 ; 146$ \\
\hline & Eurasian jackdaw (Corvus monedula) & Working memory & $103 ; 213$ \\
\hline & Eurasian jay (Garrulus glandarius) & Inhibition & $30 ; 146$ \\
\hline & Florida scrub jay (Aphelocoma coerulescens) & Working memory & $103 ; 237-238$ \\
\hline & Hooded crow (Corvus cornix) & Working memory & 98 \\
\hline & Mexican jay (Aphelocoma wollweberi) & $\begin{array}{c}\text { Inhibition } \\
\text { Working memory }\end{array}$ & $\begin{array}{c}174 ; \\
237 ; 266\end{array}$ \\
\hline & New Caledonian crow (Corvus moneduloides) & Inhibition & $54 ; 287$ \\
\hline & Large-billed crow (Corvus macrorhynchos) & Working memory & 97 \\
\hline
\end{tabular}


Red-billed blue magpie (Urocissa oecipitalis)

Pinyon jay (Gymnorhinus cyanocephalus)

Western scrub jay (Aphelocoma californica)

Barbados bullfinch (Loxigilla barbadensis) Canary (Serinus canaria) Ground finch (Geospiza sp.)

Finches (Carduelidae)

Gamebirds (Galliformes)

Gulls (Laridae)

Honeyeaters and Australian chats (Meliphagidae) New World blackbirds (Icteridae)

Parrots (Psittacidae)

Pigeons and doves (Columbidae)

Greenfinch (Carduelis choris)

Small tree finch (Camarhynchus parvulus) Tree finch (Camarhynchus sp.) Woodpecker finch (Cactospiza pallida) Zebra finch (Taeniopygia guttata) Bobwhite quail (Colinus virginianus) Domestic chicken (Gallus gallus domesticus) Guinea fowl (Numididae) Quail (Coturnix sp.) Partridge (Alectoris sp.) Pheasant (Phasianus colchicus) Herring gull (Larus cachinnans)

Noisy miner (Manorina melanocephala) Carib grackle (Quiscalus lugubris)

Great-tailed grackle (Quiscalus mexicanus)

African grey parrot (Psittacus erithacus)

Blue-and-gold macaw (Ara ararauna)

Blue-headed macaw (Primolius couloni) Blue-throated macaw (Ara glaucogularis)

Budgerigar (Melopsittacus undulatus)

Goffin's cockatoo (Cacatua goffiniana)

Great green macaw (Ara ambiguus) Kea (Nestor notabilis) Rainbow lorikeet (Trichoglossus haemotodus)

Red-shouldered macaw (Diopsittaca nobilis) Sulphur-crested cockatoo (Cacatua galerita)

Domestic pigeon (Columba livia) Black-headed caique (Pionites melanocephalus)

Orange-winged amazon (Amazona amazonica)

Yellow-headed parrot (Amazona ochrocephala) Inhibition
Inhibition

Inhibition

Working memory Shifting Inhibition

Working memory Shifting Inhibition

Working memory Inhibition

Working memory Inhibition Inhibition Inhibition Inhibition Inhibition

Working memory Inhibition

Working memory Inhibition Inhibition

Working memory

Working memory

Inhibition

Inhibition

Inhibition

Inhibition

Inhibition

Inhibition

Inhibition

Inhibition

Inhibition

Inhibition

Inhibition

Inhibition

Working memory

Inhibition

Inhibition

Inhibition

Inhibition

$26 ; 158$

$157 ; 174 ; 191 ; 200$

103; 237-238; 266

284

30; 153; 157; 174; 188-189; $266 ; 270$

284

159

246

162

240

204

162

162-163; 203-204

30

$26 ; 158$

6-7; 24-26; 158; 185; 199

$98 ; 245 ; 263$

158

246

158

$37-38 ; 56 ; 106 ; 128 ; 137$

246

$241 ; 243$

202

176

55; 154; 183; 195

171

194

55; 154

55; 154

196; 286

$139 ; 193$

$55 ; 154$

$172 ; 194$

30

242-243

171

6

$26 ; 158$

28; 30; 41; 115; 148-149; $151 ; 158 ; 175 ; 182 ; 187 ; 197$; 289

42; 72; 80; 123; 125, 127;

Working memory $140 ; 178 ; 181 ; 217 ; 219-220$;

222; 225; 228-230; 232-234, 
247-251; 252-262; 267-269;

$270 ; 273$

$114,116,118,182 ; 236$; 276-

Shifting

Ring-necked dove (Streptopelia capicola) Zenaida dove (Zenaida aurita)

Sparrows

(Passeridae)

Starlings and mynas (Sturnidae)

Swans, geese and ducks (Anatidae)

Tits and chickadees (Paridae)

Wood swallows (Artamidae)
Black-capped chickadee (Parus atricapillus)

Blue tit (Parus caeruleus)

Dark-eyed junco (Junco hyemalis)

Song sparrow (Melospiza melodia) Swamp sparrow (Melospiza georgiana)

European starling (Sturnus vulgaris)

Greater Hill myna (Gracula religiosa)

Indian myna (Acridotheres tristis)

Trumpeter (Psophia sp.)

Coal tit (Parus ater)

Great tit (Parus major)

Mountain chickadee (Poecile gambeli)

Marsh tit (Parus palustris)

Australian magpie (Cracticus tibicen dorsalis / Gymnorhina tibicen dorsalis)
279

Inhibition

Inhibition

158

Inhibition

Working memory

Inhibition

Inhibition

Working memory

Inhibition

Inhibition

Inhibition

Inhibition

Working memory

Working memory

Working memory

Inhibition

Working memory

Inhibition

Working memory

Inhibition
160

201

$124 ; 264$

132; $161 ; 177$

30

$224 ; 271-272$

27; 158

173

158

201

$124 ; 223 ; 264$

241

240

130-131

240

166-167

240

168

The lack of correlation between tasks that are assumed to engage the same cognitive processes may be caused by task-specific factors, e.g., material size or visibility, or other, species-specific and even individual-specific factors that hinder reliable cross-species comparisons. Inter-species differences in cognitive adaptations are driven by selective pressures of their physical and social environments, and intra-species differences in cognition reflect individual differences in the brain, genetic inheritance, physical environment (e.g., its predictability), social environment (e.g., social status), distinct learning experiences, and personality [58]. All these factors, as well as measurement error, must be accounted for in both intra- and inter-species studies. In fact, systematically manipulated tests of executive functions could allow for measuring these factors' contributions to individual performance and uncovering individual- and species-specific cognitive adaptations in the future.

Research on avian executive functions is hindered by low consistency in performance across different cognitive domains, which may stem from task-specific, species-specific and individual-specific factors. However, a few recent studies have shown that, despite low apparent consistency in performance across multiple tasks, a single factor may underlie performance on several of such tasks, at least in North Island robins [147] and pheasants [38]. Although this factor was termed a general cognitive factor and suggested to be analogous to human " $\mathrm{g}$ ", caution is needed when interpreting its scope and impact on cognition, as it may be susceptible to the precise composition of the multi-task battery used in a given study [38]. Testing whether a single factor could account for success rates on multiple executive function tasks in birds (and other animals) will likely become increasingly popular in the future. However, another avenue of research may flourish as well, focusing on error patterns and continuous measures of performance instead of success rates. 
Overall, cross-species comparisons of executive functions, however tempting, require a great deal of caution. Although, in principle, such comparisons have the potential to improve the current understanding of how the evolution of cognition unfolded, they must be accompanied by reflection on task-, species- and individualspecific factors that may have contributed to the observed performance. Despite decades of research on avian executive functions, relatively little is still known about relevant cognitive processes in most bird species, but this gap will likely be filled in the coming years.

Supplementary Materials: No Supplementary Materials are available for this manuscript.

Author Contributions: Conceptualization, K.B..; methodology, K.B.; investigation, K. B.; writingoriginal draft preparation, K.B.; writing - review and editing, K.B. and S.G.; visualization, K.B.; All authors have read and agreed to the published version of the manuscript.

Funding: This research received no external funding.

Institutional Review Board Statement: Not applicable.

Acknowledgments: The Authors thank Lund University (KB) and the University of Luxembourg (KB and SG) for financial support during this work.

Conflicts of Interest: The authors declare no conflict of interest.

\section{References}

1. Diamond A. Executive functions. Annu Rev Psychol 2013, 64, 135-168.

2. Miyake, A., Friedman, N. P., Emerson, M. J., Witzki, A. H., Howerter, A., \& Wager, T. D. The unity and diversity of executive functions and their contributions to complex "Frontal Lobe" tasks: a latent variable analysis. Cogn Psychol 2000, 41(1), 49-100.

3. Puig, M. V., Rose, J., Schmidt, R., \& Freund, N. Dopamine modulation of learning and memory in the prefrontal cortex: insights from studies in primates, rodents, and birds. Front Neural Circuits 2014, 8, 93.

4. Tello-Ramos, M.C., Branch, C., Kozlovsky, D., Pitera, A., \& Pravosudov, V. Spatial memory and cognitive flexibility trade-offs: to be or not to be flexible, that is the question. Animal Behav 2019, 147, 129-136.

5. Bobrowicz, K. Memory for Problem Solving: Comparative Studies in Attention, Working and Long-term Memory. PhD, Lund University, Lund, Sweden, 2019.

6. Köhler, W. The mentality of apes, 2nd ed.; Trubner \& Co, Ltd: London, 1925.

7. Thorndike, E. L. Animal intelligence: experimental studies. The Macmillan Company: New York, 1911.

8. Kabadayi, C., Bobrowicz, K., Osvath, M. The detour paradigm in animal cognition. Animal Cogn 2018, 21(1), $21-35$.

9. Dewsbury, D. A. Comparative cognition in the 1930s. Psychon Bull Rev 2000, 7(2), 267-283.

10. Hunter, W. S. Delayed reaction in animals and children. Behav Monographs 1913 ,2(6), 1-86.

11. Roberts, W. A., Santi, A. The comparative study of working memory. In APA Handbook of Comparative Psychology (Vol. 2. Perception, Learning, and Cognition; Call, J., Ed. American Psychological Association, 2017.

12. Clarke, R., Heron, W., Fetherstonhaugh, M., Forgays, D., Hebb, D. Individual differences in dogs: preliminary report on the effects of early experience. Can J Exp Psychol 1951; 5,150-156.

13. Sarris, E. G. Die individuellen Unterschiede bei Hunden. Zeitschrift für Angewandte Psychologie und Charakterkunde 1937, 52, 257309.

14. Thompson, W. R., Heron, W. The effects of restricting early experience on the problem-solving capacity of dogs. Can J Exp Psychol 1954, 8, 17-31.

15. Wyrwicka, W. Studies on detour behaviour. Behaviour 1959, 14, 240-264.

16. Harlow, H. F. Comparative behavior of primates III. Complicated delayed reaction tests on primates. J Comp Psychol 1932, 14, 241-252

17. Harlow, H. F., Bromer, J. A. The capacity of platyrrhine monkeys to solve delayed reaction tests. J Comp Psychol 1939, 28, 299304.

18. Harlow, H. F., Uehling, H., Maslow, A. H. Comparative behavior of primates I. Delayed reaction test on primates from the lemur to the orangutan. J Comparative Psychology 1932, 13, 313-343.

19. Maslow, A. H., Harlow, H. F. (Comparative behavior of primates II. Delayed reaction tests on primates at Bronx Park Zoo. J Comp Psychol 1932, 14, 97-107.

20. McAllister, W. G. A further study of the delayed reaction in the albino rat. Comp Psychol Monographs 1932, 8(2), 1-103.

21. Tinklepaugh, O. L. Multiple delayed reactions with chimpanzees and monkeys. J Comp Psychol 1932, 13, $207-243$.

22. Yudin, H. C., Harlow, H. F. Comparative behavior of primates V. Delayed reactions in primates in horizontal and vertical planes. J Comp Psychol 1933, 16, 143-146.

23. Lorenz, K. Betrachtungen über das Erkennen der arteigenen Triebhandlungen der Vögel. J für Ornithologie 1932, 80, 50-98.

24. Scholes, N. W. Detour learning and development in the domestic chick. J Comp Physiol Psychol 1965, 60, 114-116. 
25. Scholes, N. W., Wheaton, L. G. Critical period for detour learning in developing chicks. Life Sci 1966, 5, 1859-1865.

26. Gossette, R. L., Gossette, M. F., Riddell, W. Comparisons of successive discrimination reversal performances among closely and remotely related avian species. Animal Behav 1966, 14(4), 560-564.

27. Gossette, R., Gossette, M., Inman, N. Successive discrimination reversal performance by the Greater Hill Myna. Anim Behav 1966, 14, 50-53.

28. Gonzalez, R. C., Behrend, E. R., Bitterman, M. E. Reversal learning and forgetting in bird and fish. Science 1967, 158, 519-521

29. Warren, J. M., Brookshire, R. H., Ball, G. G. Reynolds, D. V. Reversal learning by white Leghorn chicks. J Comp Physiol Psychol 1960, 53, 371-375.

30. MacLean, E. L., Hare, B., Nunn, C. L., Addessi, E., Amici, F., Anderson, R. C., Aureli, F., Baker, J. M., Bania, A. E., Barnard, A. M., Boogert, N. J., Brannon, E. M., Bray, E. E., Bray, J., Brent, L. J., Burkart, J. M., Call, J., Cantlon, J. F., Cheke, L. G., Clayton, N. S., ... Zhao, Y. The evolution of self-control. PNAS 2014, 111(20), E2140-E2148.

31. Kabadayi, C. Planning and inhibition in corvids. PhD, Lund University, Lund, Sweden, 2017.

32. Lambert, M., Jacobs, I., Osvath, M., von Bayern, A. Birds of a feather? Parrot and corvid cognition compared. Behaviour 2019, 156(5-8), 505-594.

33. Güntürkün, O., Bugnyar, T. Cognition without cortex. Trends Cogn Sci 2016, 20(4), 291-303.

34. Clayton, N. S., Emery, N. J. Avian Models for Human Cognitive Neuroscience: A Proposal. Neuron 2015, 86(6), $1330-1342$.

35. Griffin, A.S., Guez, D. Innovation and problem solving: A review of common mechanisms. Behavioural Processes 2014, 109, 121134.

36. van Horik, J. O., Clayton, N. S., Emery, N. J. Convergent evolution of cognition in corvids, apes and other animals. In The Oxford handbook of comparative evolutionary psychology; Vonk, Shackelford, J. T. K. (Eds.); Oxford University Press, 2012 , pp. 80-101.

37. Madden, J., Langley, E.J., Whiteside, M., Beardsworth, C.E., Horik, J.V. The quick are the dead: pheasants that are slow to reverse a learned association survive for longer in the wild. Phil Trans Royal Soc B: Biol Sci 2018, 373.

38. van Horik, J. O., Langley, E., Whiteside, M. A., Laker, P. R., Madden, J. R. Intra-individual variation in performance on novel variants of similar tasks influences single factor explanations of general cognitive processes. Royal Soc Open Science 2018, 5(7), 171919

39. Güntürkün, O. Cognitive impairments after lesions of the neostriatum caudolaterale and its thalamic afferent in pigeons: functional similarities to the mammalian prefrontal system? J fur Hirnforschung 1997, 38, 133-43.

40. Güntürkün, O. The avian 'prefrontal cortex' and cognition. Curr Opin Neurobiol 2005, 15, 686-693.

41. Hartmann, B., Güntürkün, O. Selective deficits in reversal learning after neostriatum caudolaterale lesions in pigeons: Possible behavioral equivalencies to the mammalian prefrontal system. Behav Brain Res 1998, 96(1-2), 125-133.

42. Mogensen, J., Divac, I. The prefrontal 'cortex' in the pigeon. Behavioral evidence. Brain Behav Evol 1982, 21(2-3), 60-66.

43. Waldmann, C., Güntürkün, $O$. The dopaminergic innervation of the pigeon caudolateral forebrain: immunocytochemical evidence for a 'prefrontal cortex' in birds? Brain Res 1993, 600(2), 225-234.

44. Babb, S. J., Crystal, J. D. Episodic-like memory in the rat. Curr Biol 2006, 16(13), 1317-1321.

45. Clayton, N. S., Dickinson, A. Episodic-like memory during cache recovery by scrub jays. Nature 1998, 395(6699), $272-274$.

46. Clayton, N. S., Dickinson, A. Scrub jays (Aphelocoma coerulescens) remember the relative time of caching as well as the location and content of their caches. J Comp Psychol 1999, 113(4), 403-416.

47. Clayton, N. S., Griffiths, D. P., Emery, N. J., Dickinson, A. Elements of episodic-like memory in animals. Phil Trans Royal Soc B: Biol Sci 2001, 356(1413), 1483-1491.

48. Roberts W. A. Animal memory: episodic-like memory in rats. Curr Biol 2006, 16(15), R601-R603.

49. Schwartz, B. L., Hoffman, M. L., Evans, S. Episodic-like memory in a gorilla: A review and new findings. Learning Motivation 2005, 36(2), 226-244.

50. Schwartz, B. L., Evans, S. Episodic memory in primates. Am J Primatol 2001, 55(2), 71-85.

51. Correia, S. P., Dickinson, A., Clayton, N. S. Western scrub-jays anticipate future needs independently of their current motivational state. Curr Biol 2007, 17(10), 856-861.

52. Raby, C. R., Alexis, D. M., Dickinson, A., Clayton, N. S. Planning for the future by western scrub-jays. Nature 2007, 445(7130), 919-921.

53. Osvath, M., Osvath, H. Chimpanzee (Pan troglodytes) and orangutan (Pongo abelii) forethought: self-control and pre-experience in the face of future tool use. Animal Cogn 2008, 11, 661-674.

54. Kabadayi, C., Taylor, L. A., von Bayern, A. M., Osvath, M. Ravens, New Caledonian crows and jackdaws parallel great apes in motor self-regulation despite smaller brains. Royal Soc Open Science 2016, 3(4), 160104.

55. Kabadayi, C., Krasheninnikova, A., O’Neill, L., Weijer, J.V., Osvath, M., Bayern, A.V. Are parrots poor at motor self-regulation or is the cylinder task poor at measuring it? Animal Cogn 2017, 20, 1137 - 1146.

56. van Horik, J. O., Langley, E. J., Whiteside, M. A., Laker, P. R., Beardsworth, C. E., Madden, J. R. Do detour tasks provide accurate assays of inhibitory control? Proc. R. Soc. B 2018, 285, 20180150.

57. Bobrowicz, K., Osvath, M. Cats Parallel Great Apes and Corvids in Motor Self-Regulation - Not Brain but Material Size Matters. Front Psychol 2018, 9, 1995.

58. Boogert, N. J., Madden, J. R., Morand-Ferron, J., Thornton, A. Measuring and understanding individual differences in cognition. Phil Trans Royal Soc B: Biol Sci 2018, 373(1756), 20170280.

59. Seed, A., Emery, N., Clayton, N. Intelligence in Corvids and Apes: A Case of Convergent Evolution? Ethology 2009, 115, 401420. 
60. Benton, M. J., Donoghue, P. C. J. Paleontological evidence to date the tree of life. Mol Biol Evol 2006, 24(1), 26-53.

61. Güntürkün, O. The convergent evolution of neural substrates for cognition. Psychol Res 2012, 76(2), $212-219$.

62. Rose J., Güntürkün O., Kirsch J. Evolution of Association Pallial Areas: In Birds. In Encyclopedia of Neuroscience; Binder M.D., Hirokawa N., Windhorst U. (Eds); Springer: Berlin, Heidelberg, 2009.

63. Jarvis, E. D., Güntürkün, O., Bruce, L., Csillag, A., Karten, H., Kuenzel, W., Medina, L., Paxinos, G., Perkel, D. J., Shimizu, T., Striedter, G., Wild, J. M., Ball, G. F., Dugas-Ford, J., Durand, S. E., Hough, G. E., Husband, S., Kubikova, L., Lee, D. W., Mello, C. V., ... Avian Brain Nomenclature Consortium Avian brains and a new understanding of vertebrate brain evolution. Nature Rev Neuroscience 2005, 6(2), 151-159.

64. Herculano-Houzel, S. Birds do have a brain cortex-and think. Science 2020, 369(6511), 1567-1568.

65. Stacho, M., Herold, C., Rook, N., Wagner, H., Axer, M., Amunts, K., Güntürkün, O. A cortex-like canonical circuit in the avian forebrain. Science 2020, 369(6511), eabc5534.

66. Edinger, L., Wallenberg, A., Holmes, G. M. Untersuchungen über die vergleichende Anatomie des Gehirns. 3. Das Vorderhirn der Vogel, vol. 20. Abhandlungen der Senkenbergischen Gesellschaft, Frankfurt am Main, 1903, pp. 343-426.

67. Karten, H. J. The ascending auditory pathway in the pigeon (Columba livia). II. Telencephalic projections of the nucleus ovoidalis thalami. Brain Res 1969, 11 134-53.

68. Herold, C., Palomero-Gallagher, N., Hellmann, B., Kröner, S., Theiss, C., Güntürkün, O., Zilles, K. The receptor architecture of the pigeons' nidopallium caudolaterale: an avian analogue to the mammalian prefrontal cortex. Brain Struct Funct 2011, 216(3), 239-254.

69. Reiner, A., Yamamoto, K., Karten, H. J. Organization and evolution of the avian forebrain. Anat. Rec. A Discov. Mol. Cell. Evol. Biol. 2005, 287A, 1080-1102.

70. Shanahan, M., Bingman, V. P., Shimizu, T., Wild, M., Güntürkün, O. Large-scale network organization in the avian forebrain: a connectivity matrix and theoretical analysis. Front Comput Neurosci 2013 7, 89.

71. Shanahan, M. The brain's connective core and its role in animal cognition. Phil Trans Royal Soc B: Biol Sci 2012, 367(1603), 27042714.

72. Rose, J., Colombo, M. Neural correlates of executive control in the avian brain. PLoS Biol 2005, 3(6), e190.

73. Kröner, S, Güntürkün, O. Afferent and efferent connections of the caudolateral neostriatum in the pigeon (Columba livia): A retro- and anterograde pathway tracing study. J Comp Neurol 1999, 407, 228-260.

74. Jones, E. G., Powell, T. P. S. An anatomical study of converging sensory pathways within the cerebral cortex of the monkey. Brain 1970, 93, 793-820.

75. Shimizu, T., Cox, K., Karten, H. J. Intratelencephalic projections of the visual wulst in pigeons (Columba livia). J Comp Neurol 1995, 359, 551-572.

76. Wild, J. M., Karten, H. J., Frost, B. J. Connections of the auditory forebrain in the pigeon (Columba livia). J Comp Neurol 1993, 337, 32-62.

77. Divac, I., Mogensen, J. The prefrontal 'cortex' in the pigeon-catecholamine histofluorescence. Neuroscience 1985, 15, 677 - 82.

78. Divac, I., Thibault, J., Skageberg, G., Palacois, M., Dietl, M. M. Dopaminergic innervation of the brain in pigeons. The presumed 'prefrontal cortex'. Acta Neurobiol Exp 1994, 54, 227- 34.

79. Wynne, B., Güntürkün, O. The dopaminergic innervation of the forebrain of the pigeon (Columba livia): a study with antibodies against tyrosine hydroxylase and dopamine. J Comp Neurol 1995, 358, 1 -19.

80. Gagliardo, A., Bonadonna, F., Divac, I. Behavioral effects of ablations of the presumed 'prefrontal cortex' or the corticoid in pigeons. Behav Brain Res 1996, 78, $155-62$.

81. Güntürkün, O. Avian and mammalian "prefrontal cortices": limited degrees of freedom in the evolution of the neural mechanisms of goal-state maintenance. Brain Res Bull 2005, 66, 311-316.

82. Kirsch, J. A., Güntürkün, O., Rose, J. Insight without cortex: lessons from the avian brain. Conscious Cogn 2008, 17, 475-483.

83. Herculano-Houzel, S. Numbers of neurons as biological correlates of cognitive capability. Curr Opin Behav Sci 2017, 16, 1-7.

84. Fuster, J. M. The prefrontal cortex: Anatomy, physiology, and neuropsychology of the frontal lobe. 3rd edition. Lippincott-Raven: Philadelphia, 1997.

85. Rose, J., Schiffer, A. M., Dittrich, L., Güntürkün, O. The role of dopamine in maintenance and distractability of attention in the "prefrontal cortex" of pigeons. Neuroscience 2010, 167(2), 232-237.

86. Schnabel, R., Metzger, M., Jiang, S., Hemmings, H. C., Jr, Greengard, P., Braun, K. Localization of dopamine D1 receptors and dopaminoceptive neurons in the chick forebrain. J Comp Neurol 1997, 388, 146-168.

87. Durstewitz, D., Kröner, S., Hemmings, H. C., Jr, Güntürkün, O. The dopaminergic innervation of the pigeon telencephalon: Distribution of DARPP-32 and cooccurrence with glutamate decarboxylase and tyrosine hydroxylase. Neuroscience 1998, 83, 763-779.

88. Metzger, M., Jiang, S., Braun, K. A quantitative immunoelectron microscopic study of dopamine terminals in forebrain regions of the domestic chick involved in filial imprinting. Neuroscience 2002, 111, 611-623.

89. Durstewitz, D., Seamans, J. K., Sejnowski, T. J. Dopamine-mediated stabilization of delay-period activity in a network model of prefrontal cortex. J Neurophysiol 2000, 83, 1733-1750.

90. Schultz, W. Multiple dopamine functions at different time courses. Annu Rev Neurosci 2007, 30, 259 -288.

91. Emery, N. J., Clayton, N. S. The mentality of crows: convergent evolution of intelligence in corvids and apes. Science 2004, 306(5703), 1903-1907. 
92. Von Eugen, K., Tabrik, S., Güntürkün, O., Ströckens, F. A comparative analysis of the dopaminergic innervation of the executive caudal nidopallium in pigeon, chicken, zebra finch, and carrion crow. J Comp Neurol 2020, 528, 2929 - 2955.

93. Iwaniuk, A. N., Hurd, P. L. The Evolution of Cerebrotypes in Birds. Brain Behav Evol 2005, 65(4), $215-230$.

94. Olkowicz, S., Kocourek, M., Lučan, R. K., Porteš, M., Fitch, W. T., Herculano-Houzel, S., Němec, P. Birds have primate-like numbers of neurons in the forebrain. PNAS 2016, 113(26), 7255-7260.

95. Mello, C. V., Kaser, T., Buckner, A. A., Wirthlin, M., Lovell, P. V. Molecular architecture of the zebra finch arcopallium. J Comp Neurol 2019, 527(15), 2512-2556.

96. Prum, R. O., Berv, J. S., Dornburg, A., Field, D. J., Townsend, J. P., Lemmon, E. M., Lemmon, A. R. A comprehensive phylogeny of birds (Aves) using targeted next-generation DNA sequencing. Nature 2015, 526(7574), 569-573.

97. Goto, K., Watanabe, S. Visual working memory of jungle crows (Corvus macrorhynchos) in operant delayed matching-to-sample. Jpn Psychol Res 2009, 51(3), 122-131.

98. Lipp, H. P., Pleskacheva, M. G., Gossweiler, H., Ricceri, L., Smirnova, A. A., Garin, N. N., Perepiolkina, O. P., Voronkov, D. N., Kuptsov, P. A., Dell'Omo, G. A large outdoor radial maze for comparative studies in birds and mammals. Neurosci Biobehav Rev 2001, 25(1), 83-99.

99. Fongaro, E., Rose, J. Crows control working memory before and after stimulus encoding. Sci Rep 2020, $10(1), 3253$.

100. Ditz, H.M., Nieder, A. Sensory and Working Memory Representations of Small and Large Numerosities in the Crow Endbrain. J Neurosci 2016, 36, 12044 - 12052.

101. Rinnert, P., Kirschhock, M. E., Nieder, A. Neuronal Correlates of Spatial Working Memory in the Endbrain of Crows. Curr Biol 2019, 29(16), 2616-2624.e4.

102. Moll, F. W., Nieder, A. Cross-Modal Associative Mnemonic Signals in Crow Endbrain Neurons. Curr Biol 2015, 25(16), 21962201.

103. Gould-Beierle, K. A comparison of four corvid species in a working and reference memory task using a radial maze. J Comp Psychol 2000, 114(4), 347-356.

104. Balakhonov, D., Rose, J. Crows Rival Monkeys in Cognitive Capacity. Sci Rep 2017, 7.

105. Miller, R., Boeckle, M., Jelbert, S. A., Frohnwieser, A., Wascher, C., Clayton, N. S. Self-control in crows, parrots and nonhuman primates. Wiley Interdiscip Rev Cogn Sci 2019, 10(6), e1504.

106. van Horik, J. O., Beardsworth, C. E., Laker, P. R., Langley, E., Whiteside, M. A., Madden, J. R. Unpredictable environments enhance inhibitory control in pheasants. Animal Cogn 2019, 22(6), 1105-1114.

107. Burgess, P. W. Theory and methodology in executive function research. In Methodology of frontal and executive function; Rabbitt, P. (Ed.); Psychology Press: Hove, UK, 1997, pp. 81-116.

108. Burgess, P. W., Alderman, N., Evans, J., Emslie, H., \& Wilson, B. A. The ecological validity of tests of executive function. J Int Neuropsychol Soc 1998, 4, 547-558.

109. Duncan, J., Johnson, R., Swales, M., Freer, C. Frontal lobe deficits after head injury: Unity and diversity of function. Cogn Neuropsychol 1997, 14, 713-741.

110. Nigg, J. T. Annual research review: On the relations among self-regulation, self-control, executive functioning, effortful control, cognitive control, impulsivity, risk-taking, and inhibition for developmental psychopathology. J Child Psychol Psychiatr 2017, 58(4), 361-383.

111. Lehto, J. Are executive function tests dependent on working memory capacity? Q J Exp Psychol 1996, 49A, 29-50.

112. Lowe, C., Rabbitt, P. Cognitive models of aging and frontal lobe deficits. In Methodology of frontal and executive functions; Rabbitt, P. (Ed.); Psychology Press: Hove, UK, 1997, pp. 39-59.

113. Izquierdo, A., Brigman, J. L., Radke, A. K., Rudebeck, P. H., Holmes, A. The neural basis of reversal learning: An updated perspective. Neuroscience 2017, 345, 12-26.

114. Watanabe, S. The Neural Basis of Cognitive Flexibility in Birds. In Comparative cognition: Experimental explorations of animal intelligence; Wasserman, E. A., Zentall, T. R. (Eds.); Oxford University Press, 2009, pp. 619 - 636.

115. Husband, S., Shimizu, T. Reversal learning after lesions in the presumptive nucleus accumbens in pigeons. Proc Int Conf Comp Cogn 2003, 10, 25.

116. Watanabe, S. Effects of Wulst and ectostriatum lesions on repeated acquisition of spatial learning in pigeons. Cogn Brain Res 2003, 17, 286- 292.

117. Cohn, J., Paule, M. G. Repeated acquisition of response sequences: the analysis of behavior in transition. Neurosci Biobehav Rev 1995, 19(3), 397-406.

118. Watanabe, S. Effects of lobus parolfactorius lesions on repeated acquisition of spatial discrimination in pigeons. Brain Behav Evol 2002, 58, 333-342.

119. Benowitz, L. I., Karten, H. J. The tractus infundibulli and other afferents to the parahippocampal region of the pigeon. Brain Res 1976, 102, 174-180.

120. Bingman, V. P., Casini, G., Nocjar, C., Jones, T.-J. Connections of the piriform cortex in homing pigeons (Columba livia) studies with fast blue and WGA-HRP. Brain Behav Evol 1994, 43, 206-218.

121. Kahn, M. C., Hough, G. E., Ten Eyck, G. R., Bingman, V. P. Internal connectivity of the homing pigeon (Columba livia) hippocampal formation: An anterograde and retrograde tracer study. J Comp Neurol 2003, 459, 127-141.

122. Krebs, J. R., Erichsen, J. T., Bingman, V. P. The distribution of neurotransmitters and neurotransmitter-related enzymes in the dorsomedial telencephalon of the pigeon (Columba livia). J Comp Neurol 1991, 314, 467-477. 
123. Good, M., Macphail, E. M. The avian hippocampus and short-term memory for spatial and non-spatial information. $Q J$ Exp Psychol B 1994, 47, 293-317.

124. Hampton, R., Shettleworth, S. Hippocampal lesions impair memory for location but not color in passerine birds. Behav Neurosci 1996, 110, 831-835.

125. Colombo, M., Broadbent, N. J., Taylor, C. S. R., Frost, N. The role of the avian hippocampus in orientation in space and time. Brain Res 2001, 919(2), 292-301.

126. Colombo, M., Broadbent, N. J. Is the avian hippocampus a functional homologue of the mammalian hippocampus? Neurosci Biobehav Rev 2000, 24, 465-484.

127. Kahn, M. C., Bingman, V. P. Avian hippocampal role in space and content memory. Eur J Neurosci 2009, 30, $1900-1908$.

128. Griffin, K.R., Beardsworth, C.E., Laker, P.R., van Horik, J.O., Whiteside, M.A., Madden, J.R. The inhibitory control of pheasants (Phasianus colchicus) weakens when previously learned environmental information becomes unpredictable. Animal Cogn 2019, 23, 189 - 202.

129. Duque, J. F., \& Stevens, J. R. Cylinder task. Springer: New York, NY, 2017.

130. Isaksson, E., Utku Urhan, A., Brodin, A. High level of self-control ability in a small passerine bird. Behav Ecol Sociobiol $2018,72$.

131. Troisi, C. A., Cooke, A. C., Davidson, G. L, de la Hera, I., Reichert, M. S., Quinn, J. L. No evidence for cross-contextual consistency in spatial cognition or behavioral flexibility in a passerine. Animal Behav Cogn 2021, 8(3), 446-461.

132. Boogert, N. J., Anderson, R. C., Peters, S., Searcy, W. A., Nowicki, S. Song repertoire size in male song sparrows correlates with detour reaching, but not with other cognitive measures. Anim Behav 2011, 81,1209-1216.

133. Vernouillet, A., Anderson, J., Clary, D., Kelly, D. M. Inhibition in Clark's nutcrackers (Nucifraga columbiana): results of a detour-reaching test. Anim Cogn 2016, 19, 661-665.

134. Verbruggen, F., McAndrew, A., Weidemann, G., Stevens, T., McLaren, I. P. Limits of executive control: sequential effects in predictable environments. Psychol Sci 2016, 27, 748-757

135. Beran, M. J. The comparative science of 'self-control': what are we talking about? Front Psychol 2015, 6, 1-4.

136. Audet, J.-N., Lefebvre, L. What's flexible in behavioral flexibility? Behav Ecol 2017, 28(4), $943-947$.

137. Meier, C., Pant, S. R., van Horik, J. O., Laker, P. R., Langley, E., Whiteside, M. A., Verbruggen, F., Madden, J. R. A novel continuous inhibitory-control task: variation in individual performance by young pheasants (Phasianus colchicus). Animal Cogn 2017, 20(6), 1035-1047.

138. Anderson, M. C., Levy, B. Suppressing unwanted memories. Curr Dir Psychol Sci 2009, 18, 189-94.

139. Bobrowicz, K., O'Hara, M., Carminito, C., Auersperg, A., Osvath, M. Goffin's Cockatoos (Cacatua goffiniana) Can Solve a Novel Problem After Conflicting Past Experiences. Front Psychol 2021, 12, 694719.

140. Wright, A. A., Santiago, H. C., Sands, S. F., Kendrick, D. F., Cook, R. G. Memory processing of serial lists by pigeons, monkeys, and people. Science 1985, 229, 287-289.

141. Engelhardt, P. E., Nigg, J. T., Carr, L. A., Ferreira, F. Cognitive inhibition and working memory in attentiondeficit/hyperactivity disorder. J Abnorm Psychol 2008, 117, 591-605.

142. Friedman, N. P., Miyake, A. The relations among inhibition and interference control functions: a latentvariable analysis. J Exp Psychol Gen 2004, 133, 101-35.

143. Diamond A, Lee K. Interventions and programs demonstrated to aid executive function development in children 4-12 years of age. Science 2011, 333, 959-64.

144. Duckworth, A. L., Kern, M. L. A meta-analysis of the convergent validity of self-control measures. J Res Personal 2011, 45, 259268.

145. Muraven, M., Baumeister, R. F. Self-regulation and depletion of limited resources: Does self-control resemble a muscle? Psychol. Bull. 2000, 126, 247-259.

146. Jelbert, S. A., Taylor, A. H., Gray, R. D. Does absolute brain size really predict self-control? Hand-tracking training improves performance on the A-not-B task. Biol Lett 2016, 12, 20150871.

147. Shaw, R. C., Boogert, N. J., Clayton, N. S., Burns, K. C. Wild psychometrics: evidence for 'general' cognitive performance in wild New Zealand robins. Petroica longipes. Anim Behav 2015, 109, 101-111.

148. Meier, C., Lea, S. E. G., McLaren, I. P. L. Pigeons in Control of Their Actions: Learning and Performance in Stop-Signal and Change-Signal Tasks. J Exp Psychol Animal Learn Cogn 2018, 33, 82-94

149. Lea, S. E. G., Chow, P. K. Y., Meier, C., McLaren, I. P. L., Verbruggen, F. Pigeons' performance in a tracking change-signal procedure is consistent with the independent horse-race model. J Exp Psychol Animal Learn Cogn 2009, 45(4), 464-473.

150. Li, X., Li, B., Lages, M., Stoet, G. Commentary: Task-Switching in Pigeons: Associative Learning or Executive Control? Front Psychol 2017, 8, 1420.

151. Miller, D. B., Tallarico, R. B. On the correlation of brain size and problem-solving behavior of ring doves and pigeons. Brain Behav Evol 1974, 10, 265-273.

152. Kabadayi, C., Jacobs, I., Osvath, M. The development of motor self-regulation in ravens. Front Psychology 2017, 8, Article 2100.

153. Stow, M. K., Vernouillet, A., Kelly, D. M. Neophobia does not account for motoric self-regulation performance as measured during the detour-reaching cylinder task. Animal Cogn 2018, 21(4), 565-574.

154. Morales Picard, A. Relationship quality and cognition in orange-winged amazons (Amazona amazonica) and blue and gold macaws (Ara ararauna). PhD thesis, University of York, York, 2016.

155. Shaw, R. C. Testing cognition in the wild: factors affecting performance and individual consistency in two measures of avian cognition. Behav Process 2017, 134, 31-36. 
156. Piaget, J. The construction of reality in the child. Basic Books, 1954.

157. Bond, A. B., Kamil, A. C., Balda, R. P. Serial reversal learning and the evolution of behavioral flexibility in three species of North American corvids (Gymnorhinus cyanocephalus, Nucifraga columbiana, Aphelocoma californica). J Comp Psychol 2007, 121(4), 372-379.

158. Gossette, R.L. Examination of retention decrement explanation of comparative successive discrimination reversal learning by birds and mammals. Percept Mot Skills 1968, 27, 1147-1152.

159. Audet, J. N., Ducatez, S., Lefebvre, L. The town bird and the country bird: problem solving and immunocompetence vary with urbanization. Behav Ecol 2016, 27(2), 637-644.

160. Boogert, N. J., Monceau, K., Lefebvre, L. A field test of behavioural flexibility in Zenaida doves (Zenaida aurita). Behav Process 2010, 85(2), 135-141.

161. Anderson, R. C., Searcy, W. A., Peters, S., Hughes, M., DuBois, A. L., Nowicki, S. Song learning and cognitive ability are not consistently related in a songbird. Animal $\operatorname{Cog} n$ 2017, 20(2), 309-320.

162. Tebbich, S., Sterelny, K., \& Teschke, I. The tale of the finch: adaptive radiation and behavioural flexibility. Phil Trans Royal Soc B: Biol Sci 2010, 365(1543), 1099-1109.

163. Tebbich S, Teschke I. Coping with uncertainty: woodpecker finches (Cactospiza pallida) from an unpredictable habitat are more flexible than birds from a stable habitat. PLoS One 2014, 9, e91718.

164. Isden, J., Panayi, C., Dingle, C., Madden, J. Performance in cognitive and problem-solving tasks in male spotted bowerbirds does not correlate with mating success. Animal Behav 2013, 86(4), 829-838.

165. Lewis, J. L., Kamil, A. C. Interference effects in the memory for serially presented locations in Clark's nutcrackers, Nucifraga columbiana. J Exp Psychol: Animal Behav Process 2006, 32, 407-418.

166. Croston, R., Branch, C. L., Pitera, A. M., Kozlovsky, D. Y., Bridge, E. S., Parchman, T. L., \& Pravosudov, V. V. Predictably harsh environment is associated with reduced cognitive flexibility in wild food-caching mountain chickadees. Animal Behav 2017, 123, 139-149.

167. Tello-Ramos, M. C., Branch, C. L., Pitera, A. M., Kozlovsky, D. Y., Bridge, E. S., \& Pravosudov, V. V. Memory in wild mountain chickadees from different elevations: Comparing first-year birds with older survivors. Animal Behav 2018, 137, 149-160.

168. Ashton, B.J., Ridley, A.R., Edwards, E.K., \& Thornton, A. Cognitive performance is linked to group size and affects fitness in Australian magpies. Nature 2018, 554, 364 - 367.

169. Range, F., Bugnyar, T., Schlögl, C., Kotrschal, K. Individual and sex differences in learning abilities of ravens. Behav Process 2006, 73, 100-106.

170. Range, F., Bugnyar, T., Kotrschal, K. The performance of ravens on simple discrimination tasks: a preliminary study.Acta Ethologica 2008, 11, 34-41.

171. van Horik, J.O., Emery, N.J. Serial reversal learning and cognitive flexibility in two species of Neotropical parrots (Diopsittaca nobilis and Pionites melanocephala).Behav Process 2018, 157, 664-672.

172. O'Hara, M., Huber, L., Gajdon, G.K. The advantage of objects over images in discrimination and reversal learning by kea, Nestor notabilis. Anim Behav 2015, 101, 51-60.

173. Griffin, A. S., Guez, D., Lermite, F., Patience, M. Tracking changing environments: innovators are fast, but not flexible learners. PloS One 2013, 8(12), e84907.

174. Hile, A. G. Comparative tests of general intelligence between social and asocial North American seed-caching Corvids. Dissert Abstr Int B: Sci Engin 1999, 59(7-B), 3287.

175. Lissek, S., Diekamp, B., Güntürkün, O. Impaired learning of a colour reversal task after NMDA receptor blockade in the pigeon (Columba livia) associative forebrain (Neostriatum Caudolaterale). Behav Neurosci 2002, 116, 523-529.

176. Logan, C. J. Behavioral flexibility and problem solving in an invasive bird. PeerJ 2016, 4, e1975.

177. Soha, J. A., Peters, S., Anderson, R. C., Searcy, W. A., Nowicki, S. Performance on tests of cognitive ability is not repeatable across years in a songbird. Anim Behav 2019, 158, 281-288.

178. Diekamp, B., Kalt, T., Güntürkün, O. Working memory neurons in pigeons. J Neurosci 2002, 22(4), RC210.

179. Verbruggen, F., Logan, G. D. Automatic and controlled response inhibition: associative learning in the go/no-go and stop-signal paradigms. J Exp Psychol Gen 2008, 137, 649-72.

180. Boecker, M., Gauggel, S., Drueke, B. Stop or stop-change- Does it make any difference for the inhibition process? Int J Psychophysiol 2013, 87, 234-243.

181. Kalt, T., Diekamp, B., Güntürkün, O. Single unit activity during a go/nogo task in the "prefrontal cortex" of the pigeon. Brain Res 1999, 839, 263-278.

182. Watanabe, S. Effects of hippocampal lesions on repeated acquisition of spatial discrimination in pigeons. Behav Brain Res 2001, 120(1), 59-66.

183. Vick, S. J., Bovet, D., Anderson, J. R. How do African Grey parrots (Psittacus erithacus) perform on a delay of gratification task? Anim Cogn 2010, 13, 351-358.

184. Hillemann, F., Bugnyar, T., Kotrschal, K., Wascher, C. A. F. Waiting for better, not for more: Corvids respond to quality in two delay maintenance tasks. Animal Behav 2014, 90, 1-10.

185. Abeyesinghe, S. M., Nicol, C. J., Hartnell, S. J., Wathes, C. M. Can domestic fowl, Gallus gallus domesticus, show self-control. Anim Behav 2005, 70, 1-11.

186. Grosch, J., Neuringer, A. Self-control in pigeons under the Mischel paradigm. J Exp Anal Behav 1981, 35, 3-21. 
187. Logue, A. W., Chavarro, A., Rachlin, H., Reeder, R. W. Impulsiveness in pigeons living in the experimental chamber. Anim Learn Behav 1988, 16(1), 31-39

188. Clayton, N. S., Dally, J., Gilbert, J., Dickinson, A. Food caching by western scrub-jays (Aphelocoma californica) is sensitive to the conditions at recovery. J Exp Psychol Anim Behav Process 2005, 31(2), 115-124.

189. Thom, J. M., Clayton, N. S. No evidence of temporal preferences in caching by Western scrub-jays (Aphelocoma californica). Behav Proc 2014, 103, 173-179.

190. Stephens, D. W., Dunlap, A. S. Why do animals make better choices in patch-leaving problems? Behav Process 2009, 80(3), 252260.

191. Stevens, J. R., Kennedy, B. A., Morales, D., Burks, M. The domain specificity of intertemporal choice in pinyon jays. Psychon Bull Rev 2016, 23(3), 915-921.

192. Dufour, V., Wascher, C. A. F., Braun, A., Miller, R., Bugnyar, T. Corvids can decide if a future exchange is worth waiting for. Biol Lett 2012, 8(2), 201-204.

193. Auersperg, A. M., Laumer, I., Bugnyar, T. Goffin cockatoos wait for qualitative and quantitative gains but prefer 'better' to 'more'. Biol Lett 2013, 9(3), 20121092.

194. Schwing, R., Weber, S., Bugnyar, T. Kea (Nestor notabilis) decide early when to wait in food exchange task. J Comp Psychol 2017, 131(4), 269-276.

195. Koepke, A. E., Gray, S. L., Pepperberg, I. M. Delayed gratification: A grey parrot (Psittacus erithacus) will wait for a better reward. J Comp Psychol 2015, 129(4), 339-346.

196. Kemp, M. E. Cognition and problem solving using detour reaching and novel object tasks in the Budgerigar. Distinct Papers 2016, 29.

197. Ainslie, G. W. Impulse control in pigeons. J Exp Anal Behav 1974, 21(3), 485-489.

198. Cibulski, L., Wascher, C. A. F., Weiß, B. M., Kotrschal, K. Familiarity with the experimenter influences the performance of common ravens (Corvus corax) and carrion crows (Corvus corone corone) in cognitive tasks. Behav Process 2014, 103, $129-137$.

199. Amita, H., Kawamori, A., Matsushima, T. Social influences of competition on impulsive choices in domestic chicks. Biol Lett 2010, 6, 183-186.

200. Stephens, D. W., Anderson, D. The adaptive value of preference for immediacy: When shortsighted rules have farsighted consequences. Behav Ecol 2001, 12(3), 330-339.

201. Hampton, R. R., Shettleworth, S. J., Westwood, R. P. Proactive interference, recency, and associative strength: comparisons of black-capped chickadees and dark-eyed juncos. Anim Learn Behav 1998, 26, 475-485

202. Ducatez, S., Audet, J. N., Lefebvre, L. Problem-solving and learning in Carib grackles: individuals show a consistent speedaccuracy trade-off. Anim Cogn 2015, 18, 485-96.

203. Teschke, I., Cartmill, E. A., Stankewitz, S., Tebbich, S. Sometimes tool use is not the key: no evidence for cognitive adaptive specializations in toolusing woodpecker finches. Anim Behav 2001, 82, 945-956.

204. Tebbich S, Stankewitz S, Teschke I. The relationship between foraging, learning abilities and neophobia in two species of Darwin's finches. Ethology 2012, 118, 135-146.

205. Baddeley, A. D., Hitch, G. Working Memory. In The psychology of learning and motivation: Advances in research and theory; Bower, G. H. (Ed.); Academic Press; New York, 1974, 47-89.

206. Smith, E. E., Jonides, J. Storage and executive processes in the frontal lobes. Science 1999, 283, 1657-1661.

207. Honig, W. K. Studies of working memory in the Pigeon. In Cognitive Processes in Animal Cognition; Hulse, S. H., Fowler, H., Honig, W. K. (Eds.). Lawrence Erlbaum Associates, Inc.: New Jersey, NJ, 1978, pp. 211-248.

208. Veit, L., Nieder, A. Abstract rule neurons in the endbrain support intelligent behaviour in corvid songbirds. Nat Commun 2013 $4,11$.

209. Veit, L., Hartmann, K., and Nieder, A. Neuronal correlates of visual working memory in the corvid endbrain. J Neurosci 2014, 34, 7778-7786.

210. Ditz, H. M., Nieder, A. Neurons selective to the number of visual items in the corvid songbird endbrain. PNAS 2015, 112, 78277832.

211. Hahn, L. A., Rose, J. Working Memory as an Indicator for Comparative Cognition - Detecting Qualitative and Quantitative Differences. Front Psychol 2020, 11, 1954.

212. Bobrowicz, K., Osvath, M. Social context hinders humans but not ravens in a short-term memory task. Ethology 2020, 126(2), 125-139.

213. Scheid, C., Bugnyar, T. Short-term observational spatial memory in Jackdaws (Corvus monedula) and Ravens (Corvus corax). Anim Cogn 2008, 11(4), 691-698.

214. Becker, J. T., Morris, R. G. Working memory(s). Brain Cogn 1999, 41, 1-8.

215. Conway, A. R. A., Engle, R. W. Working memory and retrieval: a resource-dependent inhibition model. J Exp Psychol Gen. 1994, 123, 354-73

216. Kane, M. J., Engle, R. W. The role of prefrontal cortex in working-memory capacity, executive attention, and general fluid intelligence: an individual-differences perspective. Psychon Bull Rev 2002, 9, 637-71.

217. Wright, A. A., Elmore, L. C. Pigeon visual short-term memory directly compared to primates. Behav Process 2016, 123, 84-89.

218. Güntürkün, O., Ströckens, F., Scarf, D., Colombo, M. Apes, feathered apes, and pigeons: Differences and similarities. Curr Opinion Behav Sci 2017, 16, 35-40.

219. Terrace, H. S. Chunking by a pigeon in a serial learning task. Nature 1987, 325(7000), 149-151. 
220. Terrace, H. Chunking During Serial Learning by a Pigeon: I. Basic Evidence. J Exp Psychol 1991, 17(1), 81-93.

221. Wass, C., Pizzo, A., Sauce, B., Kawasumi, Y., Sturzoiu, T., Ree, F., ... Matzel, L. D. Dopamine D1 sensitivity in the prefrontal cortex predicts general cognitive abilities and is modulated by working memory training. Learn Memory 2013, $20,617-627$.

222. Santiago, H. C., Wright, A. A. Pigeon memory: Same/different concept learning, serial probe recognition acquisition, and probe delay effects on the serial position function. J Exp Psychol Anim Behav Process 1984, 10, 498-512.

223. Crystal, J. D., Shettleworth, S. J. Spatial list learning in black-capped chickadees. Anim Learn Behav 1994, $22,77-83$.

224. Comins, J. A., Gentner, T. Q. Working memory for patterned sequences of auditory objects in a songbird. Cognition 2010, 117(1), 38-53.

225. Maki, W. S. Pigeons' short-term memories for surprising vs. expected reinforcement. Anim Learn Behav 1979, 7, $31-37$.

226. Tulving, E., Markowitsch, H. J., Craik, F. I., Habib, R., Houle, S. Novelty and familiarity activations in PET studies of memory encoding and retrieval. Cerebral Cortex 1996, 6, 71-79.

227. Habib, R., McIntosh, A. R., Wheeler, M. A., Tulving, E. Memory encoding and hippocampally-based novelty/familiarity discrimination networks. Neuropsychologia 2003, 41, 271-279.

228. Grant, D. S., Roberts, W. A. Sources of retroactive inhibition in pigeon short-term memory. J Exp Psychol Anim Behav Process 1976, 2, 1-16.

229. Roberts, W. A., Grant, D. S. Studies of short term memory in the pigeon using the delayed matching-to-sample procedure. In Processes of animal memory; Medin, D. L., Roberts, W. A., Davis, R. T. (Eds.); Erlbaum: Hillsdale, NJ, 1976, pp. 79-112.

230. Roberts, W. A., Grant, D. S. An analysis of light-induced retroactive inhibition in pigeon short-term memory. J Exp Psychol Anim Behav Proc 1978, 4, 219-236.

231. Mogensen, J., Divac, I. Behavioural effects of ablation of the pigeon-equivalent of the mammalian prefrontal cortex. Behav Brain Res 1993, 55, 101-107.

232. Honig, W. K., James, P. H. R. Animal memory. Academic Press: San Diego, California, 1971.

233. Roberts, W.A., Van Veldhuizen, N. Spatial memory in pigeons on the radial maze. J Exp Psychol Anim Behav Process 1985, 11, 241-260.

234. Bond, A.B., Cook, R.G., Lamb, M.R. Spatial memory and the performance of rats and pigeons in the radial-arm maze. Anim Learn Behav 1981, 9, 575-580.

235. Spetch, M.L., Edwards, C.A. Spatial memory in pigeons in an open-field feeding environment. J Comp Psychol 1986, 100, 266278.

236. Prior, H., \& Güntürkün, O. Parallel working memory for spatial location and food-related object cues in foraging pigeons: binocular and lateralized monocular performance. Learn Mem 2001, 8(1), 44-51.

237. Kamil, A. C., Balda, R. P., Olson, D. J. Performance of four seed-caching corvid species in the radial-arm maze analog. J Comp Psychol 1994, 108, 385-393.

238. Balda, R. P., Kamil, A. C., Bednekoff, P. A., Hile, A. G. Species differences in spatial memory performance on a three-dimensional task. Ethology 1997, 103, 47-55.

239. Balda, R. P., Kamil, A. C. The spatial memory of Clark's nutcrackers (Nucifraga columbiana) in an analogue of the radial arm maze. Anim Learn Behav 1988, 16(2), 116-122.

240. Hilton, S. C., Krebs, J. R. Spatial memory of four species of Parus: performance in an open-field analogue of a radial maze. Q J Exp Psychol B 1991; 42B, 345-68.

241. Sulikowski, D., Burke, D. Food-specific spatial memory biases in an omnivorous bird. Biol Lett 2007, 3, $245 \mathrm{e} 248$.

242. Sulikowski, D., Burke, D. Win-shift and win-stay learning in the rainbow lorikeet (Trichoglossus haemotodus). J Comp Psychol 2011, 125, 143e149.

243. Sulikowski, D., Burke, D. Win shifting in nectarivorous birds: selective inhibition of the learned win-stay response. Anim Behav 2012, 83, 519-524.

244. Kamil, A. C., Jones, T. B., Pietrewicz, A., Mauldin, J. E. Positive transfer from successive reversal training to learning set in blue jays (Cyanocitta cristata). J Comp Physiol Psychol 1977, 91(1), 79-86.

245. Regolin, L., Vallortigara, G., Zanforlin, M. Object and spatial representations in detour problems by chicks. Anim Behav 1995, 49, 195-199.

246. Zucca, P., Antonelli, F., Vallortigara, G. Detour behaviour in three species of birds: quails (Coturnix sp.), herring gulls (Larus cachinnans) and canaries (Serinus canaria). Anim Cogn 2005, 8, 122-128.

247. Kalenscher, T., Güntürkün, O., Calabrese, P., Gehlen, W., Kalt, T., Diekamp, B. Neural correlates of a default response in a delayed go/no-go task. J Exp Anal Behav 2005, 84(3), 521-535.

248. Zentall, T. R., Urcuioli, P. J., Jagielo, J. A., Jackson-Smith, P. Interaction of sample dimension and sample comparison mapping on pigeons' performance of delayed conditional discriminations. Anim Learn Behav 1989, 17, 172-178.

249. Grant, D. S. Symmetrical and asymmetrical coding of food and no-food samples in delayed matching in pigeons. J Exp Psychol Anim Behav Process 1991, 17, 186-193.

250. Sherburne, L. M., Zentall, T. R. Coding of feature and no-feature events by pigeons performing a delayed conditional discrimination. Anim Learn Behav 1993, 21, 92-100.

251. Milmine, M., Watanabe, A., Colombo, M. Neural correlates of directed forgetting in the avian prefrontal cortex. Behav Neurosci 2008, 122, 199-209.

252. Blough, D. S. Delayed matching in the pigeon. J Exp Anal Behav 1959, 2, 151-160. 
253. Skov-Rackette, S. I., Miller, N. Y., Shettleworth, S. J. What-where-when memory in pigeons. J Exp Psychol Anim Behav Proc 2006, 32(4), 345-358.

254. Smith, L., Delayed discrimination and delayed matching in pigeons. J Exp Anal Behav 1967, 10(6), 529-533.

255. White, K. G. Characteristics of forgetting functions in delayed matching to sample. J Exp Anal Behav 1985, 44 (1), 15-34

256. Roberts, W. A. Distribution of trials and intertrial retention in delayed matching to sample with pigeons. J Exp Psychol Anim Behav Process 1980, 6(3), 217-237.

257. Zentall, T., Hogan, D. E., Howard, M. M., Moore, B. S. Delayed matching in the pigeon: Effect on performance of sample-specific observing responses and differential delay behavior. Learn Motiv 1978, 9(2), 202-218.

258. Zentall, T. R., Smith, A. P. Delayed matching-to-sample: a tool to assess memory and other cognitive processes in pigeons. Behav Process 2016, 123, 26-42.

259. Roberts, W. A., Strang, C., Macpherson, K. Memory systems interaction in the pigeon: working and reference memory. J Exp Psychol Anim Learn Cogn 2015, 41(2), 152-162.

260. Colombo, M., Swain, N., Harper, D., Alsop, B. The effects of hippocampal and area parahippocampalis lesions in pigeons: I. Delayed matching to sample. Q J Exp Psychol B Comp Physiol Psychol 1997, 50, 149-171.

261. Browning, R., Overmier, J. B., Colombo, M. Delay activity in avian prefrontal cortex-Sample code or reward code? Eur J Neurosci 2011, 33, 726-735.

262. Johnston, M., Anderson, C., Colombo, M. Neural correlates of sample-coding and reward-coding in the delay activity of neurons in the entopallium and nidopallium caudolaterale of pigeons (Columba livia). Behav Brain Res 2017, 317, $382-392$.

263. Nakagawa, S., Etheredge, R. J., Foster, T. M., Sumpter, C. E., Temple, W. The effects of changes in consequences on hens performance' in delayed-matching-to-sample tasks. Behav Proc 2004, 67(3), 441-451.

264. Brodbeck, D. R., Shettleworth, S. J. Matching location and color of a compound stimulus: Comparison of a food-storing and a nonstoring bird species. J Exp Psychol Anim Behav Proc 1995, 21(1), 64.

265. Hartmann, K., Veit, L., Nieder, A. Neurons in the crow nidopallium caudolaterale encode varying durations of visual working memory periods. Exp Brain Res 2017, 30, 1-12.

266. Olson, D. J., Kamil, A. C., Balda, R. P., Nims, P. J. Performance of four-seed caching corvid species in operant tests of nonspatial and spatial memory. J Comp Psychol 1995, 109(2), 173.

267. Johnston, M., Anderson, C., Colombo, M. Pigeon NCL and NFL neuronal activity represents neural correlates of the sample. Behav Neurosci 2017, 131, 213-219.

268. Riters, L.V., Bingman, V. P. The effects of lesions to the caudolateral neostriatum on sun compass based spatial learning in homing pigeons. Behav Brain Res 1999, 98, 1-15.

269. Johnston, M., Porter, B., Colombo, M. Delay activity in pigeon nidopallium caudolaterale during a variable-delay memory task. Behav Neurosci 2019, 133(6), 563-568.

270. Olson, D. J. Species differences in spatial memory among Clark's nutcrackers, scrub jays, and pigeons. J Exp Psychol Anim Behav Process 1991, 17, 363-376.

271. Zokoll, M. A., Klump, G. M., Langemann, U. Auditory short-term memory persistence for tonal signals in a songbird. J Acoust Soc Am Indexing 2007, 121, 2842-2851.

272. Zokoll, M. A., Naue, N., Herrmann, C. S., Langemann, U. Auditory memory: A comparison between humans and starlings. Brain Res 2008, 1220, 33-46.

273. Straub, R. O., Terrace, H. S. Generalization of serial learning in the pigeon. Anim Learn Behav 1981, 9(4), 454-468

274. Roberts, A. C., Robbins, T. W., Everitt, B. J. The effects of intradimensional and extradimensional shifts on visual discrimination learning in humans and non-human primates. Q J Exp Psychol B 1988, 40, 321-341.

275. Berg, E. A. A simple objective technique for measuring flexibility in thinking. J Gen Psychol 1948, 39, 15-22.

276. Darby, K. P., Castro, L., Wasserman, E. A., Sloutsky, V. M. Cognitive flexibility and memory in pigeons, human children, and adults. Cognition 2018, 177, 30-40.

277. Castro, L., Wasserman, E. A. Executive control and task switching in pigeons. Cognition 2016, 146, $121-135$.

278. Watanabe, S. Lesions in the basal ganglion and hippocampus on performance in a Wisconsin Card Sorting Test-like task in pigeons. Physiol Behav 2005, 85(3), 324-332.

279. Cook, R. G., Rosen, H. A. Temporal control of internal states in pigeons. Psychon Bull Rev 2010, 17(6), 915-922.

280. Meier, C., Lea, S. E., McLaren, I. P. Task-switching in pigeons: Associative learning or executive control? J Exp Psychol Anim Learn Cogn 2016, 42(2), 163-176.

281. Vandierendonck, A., Liefooghe, B., Verbruggen, F. Task switching: interplay of reconfiguration and interference control. Psychol Bull 2010, 136, 601-626.

282. Avdagic, E., Jensen, G., Altschul, D., Terrace, H. S. Rapid cognitive flexibility of rhesus macaques performing psychophysical task-switching. Anim Cogn 2014, 17, 619-631

283. Stoet, G., Snyder, L. H. Executive control and task-switching in monkeys. Neuropsychologia 2003, 41, 1357-1364.

284. Bond, A. B., Kamil, A. C., Balda, R. P. Social complexity and transitive inference in corvids. Anim Behav 2003, 65(3), 479-487.

285. Völter, C., Tinklenberg, B., Call, J., Seed, A. M. Comparative psychometrics: establishing what differs is central to understanding what evolves. Phil Trans $R$ Soc B 2018, 373, 20170283.

286. Chen, J., Chen, L., Yan, C., Yu, Z., Zou, Y, Sun, Y.-H. Are cognition and personality related in budgerigars? Curr Zool 2021, 1-9.

287. Teschke, I., Wascher, C.A.F., Scriba, M.F., von Bayern, A.M.P., Huml, V., Siemers, B. \& Tebbich, S. Did tool-use evolve with enhanced physical cognitive abilities? Philos Trans Roy Soc Lond B: Biol Sci 2013, 368, 20120418. 
288. Green, L., Myerson, J., Holt, D. D., Slevin, J. R. \& Estle, S. J. Discounting of delayed food rewards in pigeons and rats: is there a magnitude effect? J Exp Anal Behav 2004, 81, 39-50. 